\title{
Interakce při řešení problémově orientovaných úloh ve výuce přírodovědy
}

\author{
Tereza Češková \\ Masarykova univerzita, Pedagogická fakulta
}

\begin{abstract}
Abstrakt: Ani po více než deseti letech od zavedení klíčových kompetencí do českého kurikula nemá mnoho učitelů jasnou představu, jak je ve výuce rozvíjet. Tato studie se zaměřuje na jednu z nich - kompetenci $k$ řešení problémů. $V$ předchozím výzkumu se ukázalo, že samotné „dobré“ zadání problémově orientované učební úlohy, které dává žákům prostor analyzovat problém a hledat různá řešení, není zárukou, že bude u žáků kompetence k řešení problémů rozvíjena. Z výzkumu vyplynula potřeba zaměřit se na průběh řešení takových úloh. Cílem této studie je proto popsat, jak probíhá interakce mezi učitelem a žáky při řešení výukových situací, které jsou založeny na problémově orientovaných úlohách, a to pomocí konverzační analýzy 12 problémově orientovaných výukových situací vybraných z 10 hodin prírodovědy pořízených v letech 2010/2011 u pěti učitelů vždy ve dvou po sobě jdoucích vyučovacích hodinách. Ze zjištění mj. vyplývá, že interakce má celkově volnější charakter, role učitele je upozaděna, učitel nechává žáky odpověd' konstruovat samostatně a projevuje se ve chvíli, kdy je potřeba žákưm zúžit problémový prostor, pomoci analogií s jiným kontextem apod., nikdy však přímo nenavádí k správnému řešení ani je sám neuvádí. Liší se rovněž zpětná vazba, při níž se učitel ptá po zdůvodnění žákovy odpovědi a místo vlastní opravy či doplnění elicituje zpřesnění či další možné odpovědi. V závěru je diskutována souvislost se scaffoldingem, limity výzkumu i další možné směry bádání, které by mohly ve svém výsledku pomoci vytvořit náhled na to, jak kompetenci k řešení problémů ve výuce rozvíjet.
\end{abstract}

Kličová slova: problémově orientovaná úloha, problémově orientovaná situace, kompetence $\mathrm{k}$ řešení problémů, interakce, konverzační analýza, první stupeň

\section{Interaction While Solving the Problem-Oriented Tasks in Primary Science Education}

Abstract: It has been over ten years since the key competences were introduced into the Czech curricula; however, there are still lots of teachers who do not fully understand how to implement these competences in their teaching and instruction. This paper focuses on one of them: the problem-solving competence. In our previous research, we found that a well-designed assignment of a problem-oriented task does not guarantee developing of problem-solving competence. From our research, a need to focus on the execution of the problem-oriented task as such has emerged. The presented study aims to describe the interaction between the teacher and pupils while solving the problem-oriented situation developed around the problem-oriented task. I used the method of a conversation analysis of 15 problem-oriented situations selected from 10 primary science lessons, collected in 2010/2011 in five classes (in two subsequent lessons). My analysis shows that interactions in problem-oriented instruction have overall looser character of institutional rules; the teachers' role is rather inhibited as they let the pupils come up with their solutions more independently, intervening in the process only if necessary - e.g. to narrow down the problem space or to help by bringing an analogy from a different context. However, the teachers never provide explicit prompts leading to direct solution of the task nor reveal the correct solution. There are also differences in the way they provide feedback and rapport during the problem-oriented situations. 
50 For instance, when the teachers ask for an explanation or justification, they elicit a specification or providing other possible solutions instead of correcting the students. In conclusion, I discuss the connection between the explored interactions and scaffolding, limitations of my research and the potentials of follow-up research to understand in more depth how to support the development of pupils problem-solving competence.

Keywords: problem-oriented task, problem-oriented situation, problem-solving competence, interaction, conversation analysis, primary school

Kurikulární reforma přinesla do českého vzdělávání ideu klíčových kompetencí. Ani po deseti letech učitelé nemají jasnou představu, co tento pedagogický konstrukt znamená a jak jej ve výuce u žáků rozvíjet (což je ale de facto dle kurikula jedním z hlavních cílů vzdělávání). Tato studie se proto zaměřuje na jednu z nich - kompetenci $\mathrm{k}$ řešení problémů - a snaží se odhalit, jak vypadá interakce mezi učitelem a žáky při řešení výukových situací, které jsou založeny na problémově orientovaných úlohách.

Vymezení kličcových kompetencí v RVP ZV (2005 a následné revize) je poměrně volné a nejsou jasné teorie, z nichž jejich popisy vycházejí. ${ }^{1}$ Je zřejmé, že rozvíjení kličových kompetencí je principiálně dlouhodobým cílem. Kompetenci k řešení problémů ve výuce lze rozvíjet soustředěně, kupř. pomocí komplexních úloh typu PISA, které cílí prímo na danou kompetenci a méně pak berou ohled na obsahovou stránku (viz např. šetření PISA 2003 zaměřené mj. na kompetenci k řešení problémových úloh ${ }^{2}$ - problem-solving competence; PISA 2012 zaměřené mj. na kreativní řešení problémů - creative problem-solving competence; či PISA 2015 analyzující týmové řešení problémů - collaborative problem-solving competence) $)^{3}$. Takové úlohy vyžadují obvykle samostatný prostor i čas nad rámec běžného kurikula. Tato studie si však klade za cíl sledovat rozvíjení kompetence ( $k$ řešení problémů) ve výuce, která necílí primárně na podporu kompetencí, avšak kterou se, jak předepisuje RVP ZV, jejich rozvíjení prolíná napríč „veškerými vzdělávacími obsahy, aktivitami a činnostmi, které ve škole probíhaji““ (2016, s. 10). Předpokládám tedy, že danou kompetenci Ize kultivovat i drobnějšími úlohami, které umožňuji žákům rozvíjet určité komponenty kompetence bez nároku na komplexnost, jakou dávají úlohy zaměřené př́mo na dané téma (resp. kompetenci). Aby bylo možné takovou výuku identifikovat, bylo nutné vymezit její charakteristiky.

1 V RVP ZV (2016, s. 10) je psáno: „Jejich [kličových kompetencí] výběr a pojetí vychází z hodnot obecně přijímaných ve společnosti a z obecně sdílených představ o tom, které kompetence jedince přispívají k jeho vzdělávání, spokojenému a úspěšnému životu a k posilování funkcí občanské společnosti.“

2 České ekvivalenty pro pojmy zkoumané v šetřeních PISA vycházejí z dokumentů České školní inspekce - viz https://www.csicr.cz/Prave-menu/Mezinarodni-setreni/PISA.

3 Podrobněji na http://www.oecd.org/pisa. 


\section{Problémově orientovaná výuka}

Při uvažování o problémově orientované výuce musíme totiž zohlednit dva klíčové aspekty - zadání problémově orientovaných úloh a vlastní realizaci ve výuce. Je třeba dodat, že úlohy, jež by odpovídaly charakteristikám typické, resp. ideální problémově orientované úlohy, se ve výuce nevyskytují, at’ už pro svoji náročnost na přípravu, komplexnost, či časové nároky. Proto využívám tzv. klastrového pojetí pojmů (Gaut, 2000), resp. fuzzy pojetí konceptualizace (Slavík et al., 2013, s. 66), jež určuje, které z charakteristik jsou nezbytné a které další potřebné k tomu, abychom úlohu mohli považovat za problémově orientovanou. Tento přístup umožňuje sledovat i úlohy, které rozvíjejí dílčí části kompetence (kupř. operace vedoucí k řešení, propojování znalostí z různých kontextů apod.), avšak při současném (nutném) zachování charakteru „problémovosti“ úloh, jenž jim dává potřebný rámec. Na základě rešerše teoretických studií (podrobný popis a zdůvodnění viz studie Češková \& Knecht, 2016, na niž tento výzkum přímo navazuje) tedy definuji problémově orientovanou učební úlohu jako úlohu, která musí: (1) obsahovat neúplně strukturovaný problém ${ }^{4}$ (to znamená, že úloha není řešitelná jednoduchou aplikací známých či běžných pravidel nebo principů, alespoň jeden prvek úlohy je neúplně definovaný nebo zcela neznámý; údaje jsou méně návodné, není jasné, kdy, jak a zda vůbec dané údaje použít; nebo je třeba vzít v úvahu znalosti z jiných kontextů a jeho řešení pak obsahuje v sobě systém na sebe navazujících kroků, jež žák musí odhalit a vyřešit; viz Chi \& Glaser, 1985, s. 246-248; Jonassen, 1997, s. 68-69; Sternberg, 2009, s. 389-404); (2) umožňovat více řešení (i když učitel očekává nějakou odpověd', vede k ní více alternativních myšlenkových operací, nebo existuje více správných řešení) a zároveň musí splňovat alespoň dvě z následujících charakteristik: (3) mezioborový charakter (vyžaduje tedy užití souvislostí z různých kontextů); (4) učitel je v ní pouze zadavatelem úlohy (konstruktivistický charakter, větší aktivita je na straně žáka); (5) vychází z reálného života či ze zkušenosti žáků; a (6) je řešena ve skupině (řešení je založeno na sociokognitivním dialogu). Učební úlohy ve výuce ale nelze sledovat izolovaně, proto využivám situační pojetí a zkoumám je jako tzv. problémově orientované výukové situace, jichž je problémově orientovaná úloha základem a které mají vzhledem ke své „problémovosti“ určitý charakteristický průběh (rozpracování viz Češková, 2016).

V předchozím výzkumu (Češková \& Knecht, 2016; dále pro 2. stupeň Knecht, 2014) jsme se přesvědčili, že samotné „dobré“ zadání problémově orientované učební úlohy, které dává žákům prostor analyzovat problém a hledat různá řešení, není zárukou, že bude u žáků rozvíjena kompetence $\mathrm{k}$ řešení problémů. Z výzkumu vyplynula potřeba zaměřit se na samotný průběh řešení takových úloh, a to je právě cílem předkládané studie. Komunikace ve tř́dě je zkoumána různými způsoby - z hlediska diskurzu, rolí, skupinové interakce, dialogismu nebo např. skrze interakce mezi učitelem a žáky. Pro tuto studii z nich volím právě zkoumání interakcí prostřednictvím

4 V literatuře se objevují souběžně dva obsahem téměř synonymní výrazy ill-defined a ill-structured problems. Jonassen (1997, s. 78) je uspořádává takto: „Neúplně strukturovaným (ill-structured) problémem je neúplně definovaný (ill-defined) problém situovaný v reálném světě.“ 
52 konverzační analýzy, a to především proto, že umožňuje odhalit, jak učitel zprostředkovává obsahy (daného oboru) a dosahuje cílů (zde rozvíjení kompetence $\mathrm{k}$ řešení problémů) skrze ( $\mathrm{v}$ tomto př́padě problémově orientované) učební úlohy. ${ }^{5}$ Mojí snahou bude pomocí konverzační analýzy popsat charakteristiky interakcí při řešení problémově orientovaných učebních úloh. Kvůli snaze postihnout interakce $v$ těch situacích, které podporují rozvíjení kompetence $\mathrm{k}$ řešení problémů nejen problémově orientovaným zadáním úlohy $v$ jejich jádru, ale i způsobem řešení, jsem pro analýzu interakce vybrala pouze potenciálně kvalitnější výukové situace (viz níže; srov. Janík et al., 2013).

Interakcí rozumím vzájemné působení nebo ovlivňování (Gavora, 2005, s. 9). ${ }^{6}$ Skukauskaiteová et al. (2015) popisují různé významy, v nichž je pojem interakce užíván (interakce mezi učitelem a žáky, mezi žáky navzájem, vyučování, metoda atd.). Zde bude sledována $v$ doméně výuky, která, jak ji autoři shrnují, bere v potaz jak vzájemné působení učitele na žáky a opačně, tak další pedagogické aspekty (s. 52-53). Zatímco interakce při řešení ve výuce nejobvyklejších úloh - uzavřených, které vyžadují bud' zopakování (repeat), nebo vybavení si určité znalosti (recall), a jsou tedy na nízké kognitivní úrovni (pro český kontext viz Mareš \& Křivohlavý, 1995; Švaříček, 2011) -, tradičně sestává z jednoduchých výměn skládajících se z učitelovy otázky, odpovědi (obvykle vyvolaného) žáka a zhodnocení (obvykle stran správnosti) dané odpovědi učitelem, následuje další otázka, odpověd'...; řešení (kognitivně náročnějších) problémově orientovaných úloh vyžaduje mnohem pestřejší rejstřík učitelových reakcí, které musí být navíc jiného rázu. Projevují se zejména ve třetím kroku - zhodnocení, popř. rozvinutí žákovy odpovědi ( $F$-tah, viz níže), $\checkmark$ němž můžeme identifikovat „praktické a procedurální detaily vyučování, které učitelé v průběhu interakce běžně a v závislosti na aktuálním průběhu užívají“ (Lee, 2007 , s. 1206). Abych mohla postihnout odlišnosti a specifika interakce v problémově orientované výuce, musím získat podrobnější náhled, jak vypadá interakce v běžné výuce, již rozumím výuku, která nevychází z problémově orientované učební úlohy a v zásadě ji vnímám jako tu, o níž máme povědomí (nejen) např. z výzkumů TIMSS.

\section{Interakce ve školní třídě}

V každé komunikaci platí určitá pravidla. Pravidla běžné, všední komunikace popsali v sedmdesátých letech Sacks, Schegloff a Jeffersonová (1974). Zjistili, že i ve

5 Zkoumání výuky pohledem formálním, jak je tomu např. ve výzkumech zaměřených na dialogické vyučování sledujících tř̌eba, zda a v jaké míre jsou v situaci obsaženy předem definované indikátory, organizační formy či principy (Nystrand et al., 2003; Alexander, 2005; nebo výzkumy Ústavu pedagogických věd Filozofické fakulty Masarykovy univerzity), dle mého názoru přináší jiný typ poznání, než na jaké se zaměřuji. Konverzační analýza umožňuje pohled reflektující konkrétní situaci repliku po replice $s$ ohledem na to, jak je v komunikaci dosahováno institucionálního cíle. Nezohledňuje tedy jen formu, ale formu v návaznosti na daný kontext (podrobně kupř. v publikaci Tůma, 2017). Proto dialogické vyučování v tomto výzkumu pomíjím nebo je $v$ dalších částech pouze diskutuji.

6 K etymologii a vztahu interakce a komunikace viz Tůmu (2014). 
zdánlivě neuspořádané každodenní konverzaci jsou určitá pravidla, střídání replik ${ }^{7}$ je nějak koordinováno - mluvčí se střídají (nebo do hovoru vstupují další); obvykle nehovoři více mluvčích najednou, i když jejich krátké překrývání je běžné (jeden z mluvčích obvykle „ustoupí“), často nejsou žádné pauzy (gaps) mezi promluvami nebo jsou jen velmi krátké; mluvčí se obvykle stř́idají na tzv. místě relevantním z hlediska střídání mluvčích (dále MRP8; transition relevance place), což je místo přechodu k další replice; délka jejich replik ani délka a obsah celé sekvence nejsou dopředu stanoveny; počet mluvčích ani jejich pořadí nejsou předem známy; dopředu není jasné ani rozložení replik mezi mluvčími (distribution of turns - tedy kdo zahajuje, pokračuje, končí...).

V běžné (všední, neformální) interakci díky těmto pravidlům (podrobněji viz Sacks et al., 1974) nedochází k větším překryvům (overlap) mluvčích ani k velkým pauzám mezi replikami (gap). Porušení těchto pravidel se obvykle projevuje porušením komunikační normy jako takové (např. „skákání do řeči“ je de facto nerespektování MRP).

Interakce ve školním vyučování z výše uvedených pravidel vychází, vzhledem k institucionálnímu charakteru i cíli má však jistá specifika. Dle McHoula (1978, s. 187) patří mezi tzv. střední typ (medial type ; srov. Sacks et al., 1974, s. 729), nebot' je svázanější pravidly než běžná, všední interakce, avšak ne dogmaticky, např. proto, že není předem dáno, kdo kdy bude mluvit. Klíčovým faktem je to, že pozice prvního mluvčího je prealokována (předem určena) učiteli, což je společně s hlášením a vyvoláváním zároveň základní mechanismus minimalizující překrývání mluvčích ${ }^{10}$. Učitel je ten, který zahajuje interakci, at' už otázkou, nebo vyvoláním. Žák běžně hovoří ve chvíli, kdy je vyzván. ${ }^{11}$ Interakce probíhá následovně (viz obrázek 1):

I) začíná vždy učitel; ukončí-li repliku v MRP, pak

Ila) vybere, komu předá slovo - což vyplyne z konstrukce repliky: je-li mluvčí 1 učitel, pak vyvoláním zvolí mluvčího 2 (žáka) apod.;

IIb) nevybere dalšího mluvčího, pak (1) se další vývoj odvíjí od pravidel, která jsou institucionalizovaná - např. po odpovědi žáka následuje zpětná vazba učitele; nebo (2) pokračuje další replikou, dokud se někdo jiný nezvolí sám (self-select) -

7 Replikou (turn) rozumím řečový úsek jednoho mluvčího, než je vystříán druhým, sekvence se skládá z replik, obvykle tak, že tvoří logický celek (často párovou sekvenci, např. typu otázkaodpověd') a promluva je sémanticky nebo syntakticky aj. uzavřený celek jednoho mluvčího. Může se tedy skládat $z$ více replik (ten Have, 2007; s. 217-219; Havlík, 2012, s. 15).

8 Zde využívám zkratky, jejíž etymologii podrobně odůvodňuje Havlík (2012, s. 6).

9 Dle Sackse et al. (1974, s. 729) probíhá komunikace třemi způsoby: (1) jde o tzv. one-turn-at-time allocation, v němž může hovořit kdokoli z účastníků (např. v diskusi); druhým pólem je (2) preallocation of all turns, kde je skrze pravidla předem dáno, kdo může kdy hovořit (např. v debatě nejprve hovoři moderátor, pak někdo „pro“, pak „proti“). Třetím typem je pak mix obojího - (3) střední typ (medial type).

10 Vzhledem $\mathrm{k}$ počtu žákủ ve trídě by jinak bylo např. dvacet potenciálních začínajících mluvčích (twenty-at-time).

11 To samozřejmě neplatí vždy - ve výuce se objevují různé situace, kdy je pořádek narušen, aniž by to bylo sankcionováno, např. „skočí-li“ žák učiteli do repliky ve chvíli, kdy má nějaký problém, něčemu nerozumí apod. 
např. v případě, kdy žák odpovídá na otázku a po MRP pokračuje v odpovídání, upřesňování apod. Ve výuce má však tuto možnost zpravidla pouze učitel, proto žák bud' pokračuje, nebo po MRP učitel podává zpětnou vazbu (srov. uspořádání IRF - viz níže).

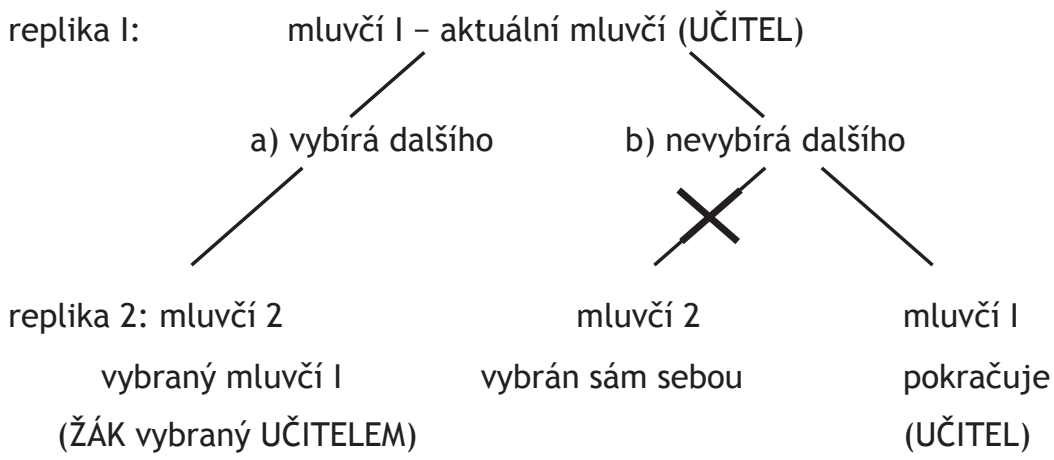

Obrázek 1 Interakce ve výuce

Další specifika interakce ve třídě, která vyplývají z programového McHoulova textu (1978), se týkají času, jejž má žák na repliku alokován. Je určen učitelem pauzy $v$ řeči mohou být - a většinou i jsou - záměrnou součástí promluvy. Tím, že učitel musí dalšího mluvčího vyvolat, může ovlivnit délku žákovy repliky, a tedy ji i prodloužit a poskytnout mu tak dostatek času na rozmyšlení odpovědi (silent time-out) beze strachu, že bude - na rozdíl od běžné mluvy - přerušen. Toto „dávání času“ je v běžné mluvě známkou formality a neužívá se (ba naopak, je běžné, že se repliky překrývají - overlap - nebo se stř́dají s minimálními pauzami - viz Sacks et al., 1974), zatímco ve školní interakci má své podstatné místo a může ovlivnit i kvalitu odpovědi (viz např. Maroni, 2011, s. 2081). Následuje-li po učitelově iniciaci príliš dlouhá pauza ${ }^{12}$, obvykle ji učitel vyhodnotí tak, že na straně žáků / vyvolaného žáka došlo $\mathrm{k}$ špatnému porozumění otázce, přeslechnutí nebo že neznají odpověd' apod., a svoji repliku reformuluje či zopakuje. Naopak žák často získává delší čas na odpověd' tím, že začne svoji výpověd' hezitačními zvuky, jako např. eh či hm, no..., čímž učiteli naznačí, že iniciaci (obvykle otázku) slyšel. Učitel obvykle odpovídá, resp. uzavírá sekvenci tím, že dá najevo, zda byla odpověd' dostatečná. Zároveň přejít $k$ dalšímu tématu, tedy ukončit sekvenci a začít další, je dovoleno pouze učiteli (resp. žákovi, pouze akceptuje-li to učitel).

12 Zde respektuji názvosloví Sackse et al. (1974), kteří rozlišují překrývání (overlap), pauzy mezi replikami (gaps) a chyby (lapses) pro případ, kdy první mluvčí skončí svoji repliku a ani on, ani nikdo další nezačne jinou. 
Výše popsané střídání replik ukazuje typickou triádu, která se v interakci ve třídě objevuje ${ }^{13}$ - IRF (Sinclair \& Coulthard, 1975; Nassaji \& Wells, 2000). ${ }^{14}$ Spočívá ve třech krocích: iniciaci-odpovědi-zpětné vazbě/navázání (angl. initiation-responsefeedback - viz Sinclair \& Coulthard, 1975; nebo follow-up - viz Wells, 1993). Uvádí se, že ve výuce na sekundárním stupni převažuje nad ostatní interakcí až 70 \%, stejně tak na primárním stupni je dominantní formou (např. Wells, 1993) a je spojena především s uzavřenými otázkami, jejichž odpověd' spočívá v učiteli známé krátké informaci, již učitel bud' vyhodnotí jako správnou, nebo ji opraví. Odpovědi jsou tak stručné, úzce vymezené, a tedy minimalizující podíl žáků na rekonstruování poznání (Chin, 2006). Lemke (1990) popisuje v triadické interakci mezi učitelem a žáky několik opakujících se vzorců: (a) série učitelských otázek (teacher question series), což je sekvence otázek (často využívající strukturu IRF), které jsou významově vázány k tématu a dohromady tvoří celek; (b) výběr a modifikace (selection and motivation), v nichž učitel využije (správnou) část (špatné, neúplné či ne zcela správné) žákovy odpovědi a poopravenou ji využije k další nápovědě; (c) zpětná rekontextualizace (retroactive recontextualization) - využití žákovy odpovědi v jiném kontextu, v němž se stává správnou, jde tudíž o zpětnou změnu významu dané odpovědi; (d) společné konstruování odpovědi (joint construction) vzájemným doplňováním (bliží se ale uzavřeným otázkám, na něž žáci hledají často jednoslovnou odpověd' pozn. autorky); a (e) dialog založený na textu (external text dialogue) - v situaci, kdy např. uzavřené zadání z učebnice učitel doplní rozvíjející otázkou.

Z hlediska kladení otázek je popisováno užívání neadresných otázek (McHoul, 1978). Každý může být potenciálně vyvolán. Pokud se situace výrazně vymkne z pravidel (platných pro danou situaci), učitel ji může vyřešit tak, že ji zastaví a „vrací“ ji zpět tím, že začne striktně (alespoň na chvíli) požadovat dodržování institucionálních způsobů - např. hlášení a vyvolávání (ibid.). Další možností je, že zopakuje otázku, pobídne žáky k přemýšlení apod., zkrátka opět převezme vedení, a nabízí tak vlastně znovu iniciaci čili formálně navrácení k pravidlům interakce ve třídě. Zastavením promluv rovněž vytváŕí prostor pro vybraného, resp. vyvolaného (selected) žáka.

Ztotožňuji se s Ingramovou a Elliottovou (2014, s. 1), jež shrnují, že ve výuce není jeden typ IRF struktury, ale párová sekvence otázka-odpověd' následovaná třetím tahem, jenž sekvenci bud' ukončuje (closing down), nebo naopak začíná další proces, jímž učitel dovádí žáky k cíli (k vyřešení úlohy). F-tah tedy ovlivňuje další vývoj interakce - má funkci nejen evaluační (at' už feedback, nebo follow-up), ale učitel skrze něj dává zároveň najevo, jak (kvalitativně) je odpověd’ produkována - např. přesně, přesvědčivě, nejistě; i v případě správné odpovědi nadto často slouží jako výzva k doplnění, přeformulování či vysvětlení odpovědi apod. (viz Nassaji \& Wells,

13 S vědomím, že jde o zjednodušující pohled hledající integrující vzorec ve složité realitě (srov. Mareš, 2016).

14 Mehan (1979) v tomto smyslu užívá IRE (iniciation-reply-evaluation). Autorka textu vidí třetí tah více formativně, často jako př́ležitost k dalšímu promýšlení, otázce, která navazuje, popř. jako propojení s další fází řešení (problémově orientované) pod/úlohy, a proto se kloní k triádě IRF. 
562000 , s. 380; Lee, 2007, s. 1205). F-tah je prostředkem k dosahování žádoucího organizačního pořádku (viz výše), zároveň ale jeho úzké pojetí ve formě prostého zhodnocení správnosti žákovy odpovědi či strhnutí aktivity na učitele vede často ke snížení aktivity žáků, a tedy k redukování i jejich (tolik žádoucího) podílu na konstruování znalostí (srov. Lee, 2007). Pakliže učitel v F-tahu reaguje na žákovu odpověd' vysvětlením (ne)správnosti dané odpovědi nebo další otázkou, která směřuje na rozvedení odpovědi (typově např. otázka Proč je to důležité?), považuje to např. Nystrand et al. (2003) za hodnocení vysoké úrovně (high-level evaluation). Protože jsou problémově orientované úlohy $z$ povahy otevřené a vždy směřují na vyšší kognitivní úroveň, vyžadují právě tento typ hodnocení. Za dominující podobu opravy ve školní výuce pak lze považovat repliku (F-tah), v níž učitel v rámci „zopakování“ žákovy odpovědi nahradí nesprávnou část tak, aby odpověd’ byla správná (srov. Nassaji \& Wells, 2000, s. 400).

\section{Zkoumání interakce ve výuce přírodovědných předmětů na 1 . stupni}

Jak upozorňuje Mareš (2016), ve výzkumech interakce ve škole se od formy - tedy podob struktury IRF - postoupilo k hledání významů. U studií zabývajících se interakcí mezi učitelem a žáky ve výuce prírodovědných předmětů na 1 . stupni (jichž v posledních zhruba 15 letech, na rozdíl od např. jazykově orientovaných, vskutku není mnoho) to můžeme pozorovat kupř. na mikroanalytických přistupech McMahonové (2012), jež zkoumala interakci učitele se třídou optikou př́padové studie u dvou učitelů-expertů přírodních věd na 1 . stupni. Konstatuje mimo jiné, že $v$ téměř všech dvaceti zkoumaných hodinách převažuje interakce učitele s celou tř́dou, přičemž podrobněji popisuje interaktivní dialogické přistupy jako sdílení nápadů, objasňování významu pojmů či debatování o řešení. Podobný přistup zvolil i Nomlomo (2010), jenž zkoumal střídání replik ve výuce př́rodních věd na 1 . stupni u dvou jihoafrických učitelů. Ve svých mikroanalýzách popisuje mj. mechanismy sborové odpovědi žáků na učitelovy uzavřené otázky či užití repetice při zavádění nového pojmu a dává je do souvislosti s autoritativním stylem výuky orientovaným na učitele a nízkou kognitivní náročností úloh. Vzdělávací kontext je sice odlišný, nicméně potvrzuje aktuální trend hledat souvislosti mezi činnostmi učitele a žáků v jejich vzájemné interakci.

Woods-McConneyová, Wosnitza a Sturrocková (2016) zase pomocí zkoumání interakce ukazují na mezery ve využití některých aktuálně preferovaných př́stupů konkrétně zkoumali skupinovou interakci při badatelské výuce prírodních věd na 1. stupni. Všimli si, že ačkoli se v každé z pozorovaných hodin objevily obsahově zaměřené interakce vysoké úrovně, byly spiše zřídkavé a velmi krátké. Často byly hned $v$ počátku utlumeny tím, že iniciativu převzal učitel, nebo se nerozvinuly, protože si žáci nebyli vědomi toho, že je úloha badatelsky orientována, a potenciál tak dle autorů nevyužili. Tato studie je inspirativní v pokusu nahlédnout, jak skutečně probíhá výuka deklarovaná jako badatelsky orientovaná. Interakcí ve skupině 
se zabývaly i Maloneyová a Simonová (2006). Zkoumaly podoby interakce žáků při řešení skupinových úloh zaměřených na rozhodování (decision making) ve výuce přírodních věd na 1. stupni. Hodnotily podoby diskusí a tvořily argumentační mapy, na nichž ukazovaly úrovně diskusí nad řešením v závislosti na typu argumentování. Z výsledků vyplývá, že nejhojněji zastoupeným typem byla diskuse, v níž argumenty vedly $\mathrm{k}$ postupnému vylepšení odpovědi, a typ, v němž postupně každý řekne svoji odpověd', z niž žáci bez podrobnější debaty jednu zvolili jako nejlepší.

Další skupina výzkumů v této oblasti se zabývá interakcí učitele se třídou (whole-class interaction), a to např. u Nassajie a Wellse (2000), kteři ve výuce prírodních věd a literatury (polovinu vzorku tvořily hodiny z 1 . stupně) identifikovali šest způsobů, jakým může být proveden F-tah ze strany učitele, a to hodnocení, zdůvodnění, protiargument, objasnění, meta-talk a akce. Zatímco evaluativní zpětná vazba (hodnocení) užívaná typicky při úlohách s jasnou správnou odpovědí (known information issues) je spojena s nižší aktivitou studentů, užití ostatních druhů zpětné vazby společně s úlohami, u nichž je třeba, jak autoři uvádějí, odpověd' složitěji hledat a vyjednávat, má na zapojení žáků pozitivní efekt. Podobný pozitivní význam uvádějí autoři i u otázek nižší kognitivní náročnosti, u jejichž řešení učitel následně vyžaduje zdůvodnění, propojení s předchozími znalostmi nebo protiargument.

Zkoumání interakce umožňuje identifikovat praktické a procedurální detaily vyučování, které učitelé v interakci používají. Touto perspektivou se budu snažit na zkoumání interakce při problémově orientované výuce dívat i v této studii. Je však patrné, že nahližení reality pouze skrze výše uvedené kategorie je značně zjednodušené. Většina popsaných teoretických studií i výzkumů se zabývala interakcí ve výuce obecně, nezaměřovaly se na žádnou konkrétní výukovou metodu či princip. Lze předpokládat, že interakce $v$ problémově orientované výuce může být v mnohém odlišná. $V$ této studii mne proto budou zajímat specifika interakce při řešení problémově orientovaných úloh.

\section{Metodologie}

Celý postup kopíruje vlastně Gadamerův hermeneutický kruh ${ }^{15}$ (východiska viz např. Konečná, 2007) - aby bylo možné popsat, jak vypadá interakce při řešení problémově orientovaných úloh, je třeba nejdřiv vymezit, co je problémově orientovaná výuka a jaké podoby v ní může interakce mít. Identifikovat tyto charakteristiky lze ale pouze přes dosavadní porozumění, které skrze výzkumná zjištění doplňujeme a zpřesňujeme. Tak jsem nejdřive na základě teoretického ukotvení popsala ideální průběh problémově orientovaných situací (viz model problémově orientované výukové situace in Češková, 2016) i podoby interakce ve výuce (viz níže), takové situace jsem následně identifikovala ve výzkumném vzorku a podrobila je dalšímu zkoumání s cílem podrobněji popsat, jaké charakteristiky interakce v problémově

15 Daný postup využili ve svém výzkumu o učitelích-expertech Píšová et al. (2013). 
58 orientované výuce vykazuje. Pomocí ideálu tak nahližím ostatní situace a postupně zpřesňuji popis ideálu.

Cílem je odpovědět na otázku, jak probíhá interakce mezi učitelem a žáky při řešení problémově orientovaných úloh na 1 . stupni ( $v$ prírodovědě). Př́stup bude stavět na etnometodologické konverzační analýze, nebot' se budu zabývat tím, jak je $\checkmark$ dialogu mezi učitelem a žáky konstruováno řešení problémově orientované úlohy jakým způsobem interakce probíhá, jaké prostředky učitel využívá atp. Podrobný náhled pomocí konverzační analýzy vyžaduje bottom-up př́stup, protože z podstaty zvolené metody při analyzování vycházím induktivně z dat, nikoli z kategoriálních systémů.

\subsection{Metoda}

Interakci ve třídě lze studovat mnoha přístupy (srov. Markee, 2015). Vzhledem k cíli studie jsem zvolila konverzační analýzu (ten Have, 2007), která se zaměřuje na popis a vysvětlení organizační struktury a vzorců, jež se v komunikaci mezi učitelem a žáky vyskytují.

Konverzační analýza (dále KA) je metoda, pomocí níž lze zkoumat interakci. Vyvinula se $v$ sedmdesátých letech $z$ etnometodologie zabývající se sociálními interakcemi. Pưvodně se snažila postihnout pravidla běžné interakce (např. Sacks et al., 1974), následně byla aplikována při zkoumání organizace institucionální interakce - a tedy i ve školní tř́dě (např. McHoul, 1978). V poslední době je užívána i pro zkoumání interakce ve výuce specifických (kupř. přírodovědných) předmětů (např. Chin, 2006; Ingram, Pitt, \& Baldry, 2015). O jejích východiscích a použití pro zkoumání interakce ve výuce $v$ češtině viz zejména Tůmu (2016). Základní princip KA spočivá $v$ tom, že předpokládá $v$ interakci určitý organizační raád a jejím cílem je jej odhalit. Výpovědi jsou v ní chápány jako „formy akce situované ve specifickém kontextu a designované s ohledem na tento kontext" (Goodwin \& Heritage, 1990, s. 287), předpokládá tedy, že $v$ interakci fungují určitá pravidla (resp. metody nebo procedury - viz Heritage, 1984, in Ingram \& Elliott, 2016), pomocí nichž je interakce účastníky strukturována a interpretována a na něž účastníci reagují. Jak rozvádí Tůma (2016), konverzační analýza z podstaty pracuje se vzájemným porozuměním účastníků, což dávají najevo tím, jak se chovají, co říkají atp. Zároveň je však třeba mít na paměti, že konverzační analýza postihuje pouze to, co je pozorovatelné (reakce, akce následující po..., způsoby komunikace atp.), avšak nikoli záměry učitele apod.

Konverzační analýza si všímá tří základních jevů - střídaní replik (turn-taking), párových sekvencí (adjacency pairs) a oprav (repairs). Tyto mechanismy byly popsány $v$ první kapitole, a to se zaměřením na interakci ve školní tříě. Párové sekvence, tedy sekvence tvořené replikami dvou mluvčích, v nichž jedna předpokládá druhou, se ve třídě projevují zejména v podobě otázka-odpověd', a zároveň bývají typicky doplněny ještě třetí částí - opravou, hodnocením nebo komentářem - podrobněji viz IRF struktura výše, přičemž u oprav si všímáme především toho, kdo opravy iniciuje 
a jakým způsobem je kdo provádí (a iniciuje-li je učitel, pak jakým způsobem žáky

k opravování vede; k opravám viz Schegloff, Jefferson, \& Sacks, 1977). Předkládaný výzkum využivá $K A$ ve všech třech oblastech, avšak ve specifickém kontextu výukových situací, $v$ nichž se řeši problémově orientované úlohy (srov. zkoumání interakce $v$ souvislosti s prostředím in Rusek et al., 2015). Použita tedy bude aplikovaná konverzační analýza (více viz ten Have, 2007, s. 173-181), nebot' se budu zabývat interakcí ve výuce (institucionální), jež je ovlivněna (výukovým) cílem a řídí se určitými pravidly.

Pomocí KA sleduji na konkrétních př́padech obecné koncepty (ten Have, 2007, s. 149) - cílem je postihnout principy a pravidla, která se v interakci vyskytují. Během tohoto procesu dochází k analytické generalizaci, která (na rozdíl od statistické generalizace - viz ten Have, 2007, s. 150) každý případ vidí jako součást budované teorie (limitované $v$ tomto prípadě specifiky interakce při řešení problémově orientovaných úloh), a vše, co se od teorie (vzorců, pravidel a principů) odlišuje, vidí jako „deviantní př́pad“. Proto v souladu s ten Havem (2007) popíšu obecnější charakteristiky, jak se ve zkoumaném vzorku objevily, přičemž vše ilustruji na konkrétních př́kladech, avšak odchylky od budované teorie pominu. 16

\section{$4.2 \mathrm{~K}$ problému validity}

V KA jde o interpretaci dané situace konkrétním výzkumníkem. Jak uvádí Maxwell, výzkumníkův vliv v kvalitativním výzkumu nelze eliminovat, je možné mu pouze porozumět. Proto jsem uvedla podrobně svá východiska a využila jsem strategie, jež mohou pomoci testovat validitu uvedených závěrů (viz Maxwell, 2010, s. 282-286; Cohen, Manion, \& Morrison, 2011, s. 181-185) - opakovaná pozorování, podrobná popisování a analyzování videozáznamů a doslovných transkriptů, vyhledávání a popis př́padů ( $v$ tomto případě výukových situací), jež jsou v rozporu s budovanou teorií, dokládání př́klady z transkriptů a srovnání s dalšími výzkumy. Ve svém výzkumu se tedy hlásím k emické perspektivě, jež vychází z dat (data-driven), a každý popsaný závěr lze doložit konkrétními replikami/sekvencemi.

\subsection{Výzkumný vzorek}

Výzkumný vzorek tvořilo 10 videozáznamů výuky přírodovědy $v 5$. ročníku pořízených $v$ rámci IVŠV videostudií ve školním roce 2010/2011, a to u pěti učitelů vždy ve dvou po sobě jdoucích vyučovacích hodinách. Všechny videozáznamy jsem dále podle transkripčních konvencí ten Hava (2007) zpracovala v programu oTranscribe, který umožňuje videozáznam podrobně komentovat a poznámkovat i neverbální jevy (clues in the video - vodítka), např. vyvolání pokynutím, souhlas pokýváním, mimika obecně ( $v$ transkriptech zapsány ve dvojitých závorkách), což se pro analýzu jeví jako nezbytné.

16 Nebot' předpokládám jejich podrobnější analýzu v další fázi výzkumu - viz diskuse. 
V předchozí fázi výzkumu (viz Češková \& Knecht, 2016) jsme ve výzkumném vzorku identifikovali 41 problémově orientovaných úloh (dále PO úloh), jež byly soustředěny $\mathrm{v} 31$ problémově orientovaných výukových situacích (dále PO výukových situacích). $V$ každé PO výukové situaci jsme pak popsali, které fáze problémově orientované výukové situace (F1 - iniciování PO úlohy, F2 - analyzování PO úlohy, F3 - vyhledávání informací, F4 - syntetizování výsledků/řešení, F5 - sumarizování výsledků/řešení, F6 - prezentování výsledků/řešení, F7 - reflektování procesu řešení) obsahují.

Jak bylo uvedeno výše, není nezbytně nutné - a ani obvyklé -, aby výukové situace obsahovaly všechny fáze, resp. aby analyzované situace měly ideální průběh. $\checkmark$ souladu se zásadami konstruktivistických přístupů ve výuce a důrazem na geneticko-sokratovské postupy coby znak kvalitní výuky z hlediska procesu didaktické transformace (viz Klieme, Schümer, \& Knoll, 2001, s. 51) považuji za potenciálně kvalitnější PO výukové situace (a tudíž jsem je zařadila do tohoto výzkumného vzorku) ty, které věnují větší část svého času fázím orientovaným na vlastní řešení PO úlohy (tedy fáze $2,3,4$ a $7{ }^{17}$ ). Při posuzování kvality PO výukové situace jsem se soustředila na formální stránku, kterou jsem však díky zvolené metodě posuzovala zásadně s ohledem na to, co ve výuce probíhalo, tedy i na oborové souvislosti. Oproti předchozímu textu (Češková \& Knecht, 2016) jsem se rozhodla zařadit mezi fáze orientované na vlastní řešení PO úlohy i fázi F5 (sumarizování), nebot' v něm často dochází ke shrnutí, zexplicitnění či zařazení do širšího oborového kontextu. To pomáhá usadit do dosavadní struktury znalostí to, co se žáci zásluhou PO úlohy naučili, což je důležité jak z hlediska budování znalostí, tak i rozvíjení klíčových kompetencí. Jak se nyní, v kvalitativní části výzkumu, ukázalo, původním vynecháním fáze 5 - sumarizování - jsem ztratila podstatnou část výukového procesu. ${ }^{18}$ Podrobnější analýze tudíz bylo podrobeno 12 PO výukových situací - optikou kritérií pro posuzování kvality výukových situací (viz Janík et al., 2013, s. 235) 12 rozvijejících situací. Vybrané situace jsou rozprostřeny s výjimkou tří vyučovacích hodin v celém zkoumaném vzorku, resp. s výjimkou jedné vyučující u všech zkoumaných učitelů.

17 F7 (reflektování procesu řešení) byla v předchozích studiích, které představují východiska pro tuto analýzu, hodnocena jako fáze, která řešení problému doplňuje. Na základě podnětu recenzenta této studie však musím přehodnotit toto stanovisko - uvědomění si a zhodnocení, jak problémově orientovanou úlohu žáci řešili, je pro rozvíjení kompetence podstatné právě tím, že se žáci učí přemýšlet nad způsoby řešení, nikoli pouze nad vyřešením úlohy. Děkuji recenzentovi, že mne k tomuto poznání přivedl. Bohužel musím ale také konstatovat, že F7 nebyla identifikována $\checkmark$ žádné ze sledovaných hodin.

18 F5 byla mezi tyto fáze zařazena ale pouze $v$ tom případě, že trvá kratší dobu než součet fází 2 , 3,4 , tedy tehdy, když převažovalo řešení $P O$ úlohy, v němž větší iniciativa byla ponechána žákům než učiteli při sumarizování. Celkový počet $P O$ výukových situací, v nichž fáze orientované na řešení PO úlohy, tedy $\mathrm{F} 2,3,4$ a 5 , v součtu zabírají víc než polovinu času, je 19 , na základě kritéria týkajícího se $\mathrm{F} 5$ bylo vyřazeno 7 PO výukových situací. 


\section{Výsledky}

Interakce během řešení problémově orientovaných úloh je samozřejmě v mnohém obdobná jako u řešení běžných, tedy neproblémově orientovaných úloh. Zároveň jsou ale patrná specifika, která jsou dána povahou problémově orientované úlohy (viz výše). Výsledky rozdělím do dvou částí: (1) průběh interakce / organizační rád, ve které popíšu obecnější jevy interakce mezi učitelem a žákem/žáky a mezi žáky navzájem; a (2) role učitele, v niž chci prezentovat způsoby, kterými učitel reaguje na repliky žáků $v$ různých fázích řešení PO úlohy.

Popisované jevy budu demonstrovat príklady ze zkoumaných transkriptů. Každý výňatek $z$ transkriptu je označen kódem, jenž sestává $z$ označení učitele $(A-E)$ a $z$ čísla problémově orientované situace (očíslováno napříc celým vzorkem). ${ }^{19}$ Ve snaze ukázat popisované jevy $v$ kontextu ostatních replik, což je pro konverzační analýzu kličové, uvádím rovněž dvě ukázky, jež byly vybrány s ohledem na množství popisovaných jevů, které $v$ nich lze $v$ kontextu demonstrovat (vzhledem ke své délce jsou uvedeny $v$ príloze). Ukázka 1 pochází $z$ hodiny učitelky $C$ zaměřené na fylogenetický vývoj člověka a zachycuje její střední část. Činnosti prezentované v ukázce předcházela úloha shrnující taxonomické zařazení člověka a úloha, $v$ níž měli žáci posoudit, čím se člověk odlišil od svých živočišných předchůdců. Během společné kontroly všechny správné odpovědi učitelka zapisovala v bodech na tabuli. Ukázka 1 zachycuje část jejich následného uspořádání dle postupu evoluce člověka, přičemž v (zde již neuvedeném) závěru výukové situace učitelka konstatuje, že „souvisí jedno s druhým" a že další kauzalitu už nelze přesně určit. Z hlediska času jde o zhruba třetinu $z$ téměř desetiminutové $P O$ výukové situace a můžeme $v$ ní pozorovat tři $P O$ úlohy z celkových osmi PO úloh, které celou PO výukovou situaci tvoří (řešení úloh nejsou lineární, navzájem se prolínají), a to: Co si myslíte, že bude jedno z prvních, čím se teda ten člověk začal od těch svých živočišných přibuzných lišit? Čím [proč] si myslíte, že je to výhodný se [napřimit]? a Co nám z toho vyplynulo, z toho vzprímeného pohybu?20 Z hlediska oborového jsou v uvedené ukázce pozorovatelná pro 1. stupeň typická didaktická zjednodušení (srov. Knecht, 2007), a to např. ve stírání rozdílu mezi živočišnými předchůdci člověka a jinými vývojovými liniemi. ${ }^{21}$

Druhou ukázku, na níž budu demonstrovat některá svá tvrzení, jsem vybrala z poslední části hodiny učitelky A. Celá hodina byla věnována ekosystému rybníka

19 Např. AS4 tedy označuje situaci v hodině učitele $A$, která je $v$ pořadí všech identifikovaných problémově orientovaných situací ve vzorku čtvrtá. Pro tuto analýzu byly ze všech problémově orientovaných situací ve vzorku vybrány pouze některé (viz výše).

20 Všechny tři úlohy považuji za $\mathrm{PO}$, nebot' jsou založeny na neúplně strukturovaném problému, jejich řešení tedy nespočivá v jednoduché odpovědi využívající dosavadní znalosti, ale je nutná jejich syntéza, žáci v úvahách musejí postupovat ve více krocích, které ale nejsou předem ani známé ani řešitelné aplikací nějakého zažitého postupu řešení; úlohy mají více správných řešení nebo k nim vede více zpưsobủ řešení, všechny jsou navíc mezioborové (minimálně propojují vlastivědné učivo s přírodovědným, resp. tematické okruhy Rozmanitost př́rody a Člověk a jeho zdraví - viz RVP ZV, 2016); u prvních dvou je učitel upozaděn a řešení pouze moderuje; druhá a třetí úloha pak využívá mj. i přímé zkušenosti žáků.

21 To je z hlediska oborové správnosti poněkud sporné - a za podnět děkuji redakčnímu vyjádření. 
62 a zvolené ukázce předcházelo opakování znalostí o kaprovi a hledání rozdílů mezi kaprem a štikou. Ukázka 2 je součástí problémově orientované situace věnující se etickému rozměru tématu zaměřenému na rozložitelnost odpadků z různých materiálů, a tedy na jejich škodlivost pro daný ekosystém. V uvedené ukázce hodiny vidíme poslední část této situace, která upozorňuje rovněž na možné společenské postihy znečišt’ování přírody odpadky. Učitelka nasimulovala situaci, v níž žáci modelovali rybník. Pak do něj někdo nasypal odpadky a žáci se stali policisty, již hledali způsoby, jak s nastalou situací naložit. Ukázka 2 popisuje další fázi hry v rolích, v níz se z žáků stali soudci, kteři mají pachatele potrestat. ${ }^{22} \mathrm{~V}$ přepisu vidíme část $\mathrm{PO}$ výukové situace, která je založena na řešení jediné PO úlohy týkající se hledání způsobu potrestání viníka znečištění. ${ }^{23}$

\subsection{Průběh interakce / organizační řád}

Interakce při řešení PO úlohy má v porovnání s běžnou (neproblémově orientovanou) výukou celkově volnější pravidla, což patrně souvisí s tím, že aktivita je přikloněna více na stranu žáků, kteří (ve sledovaných situacích) nejčastěji společně promýšlejí řešení a učitel působí spiše jako „moderátor“ (viz níže). Učitelé v analyzovaných záznamech typicky pokládali otázky žákům neadresně. Směřují tedy $\mathrm{k}$ celé třídě a odpovídá kdokoli, kdo zná odpověd', aniž by byl vyvolán - nominován učitelem (ukázka 1, ř. 1-4, 15, 36-37 atp.). Jak je vidět i z přiložených transkriptů, interakce se blíži diskusi, v niž je na rozdíl od frontální výuky akceptovatelné, že si žáci berou slovo bez vyvolání, reagují jeden na druhého (ukázka 1, ř. 41-43), navazují na sebe, často dovysvětlují odpověd' předchozího mluvčího-žáka, podporují nebo rozvíjejí tvrzení někoho jiného (ukázka 1 , r. 40,45 ), polemizují, opravují a rozporují (ukázka 1 ř. 21), někdy dokonce i repliky učitele. Učitel každou sekvenci ale začíná a končí (at' už hodnocením, nebo navedením $\mathrm{k}$ dalšímu řešení). Tím dosáhne také toho, že pokud se pravidla až príliš rozvolní a mluví např. více žáků najednou (ukázka 1, ř. 8-10), dokáže je jednoduše znovu nastolit - např. prostým adresným vyvoláním (ukázka 1, ř. 11), čímž jednak zastaví ostatní mluvčí a jednak zaměří pozornost všech na odpověd' vyvolaného žáka. Do diskuse se snaží zapojit co nejvíce žáků, v čemž hraje zásadní roli poměrně dlouhý čas, který dává žákům na přemýšlení ( $v$ transkriptech značen číslem $v$ závorce), a to i ve chvíli, kdy se několik žákủ již hlásí s odpovědí (ukázka 1, ř. 30) a (zpravidla na konci sekvence) dává prostor těm žákům, jejichž odpovědi dosud v diskusi zanikly (ukázka 2, ř. 19-20).

22 Po připomínce redakce jsem promýšlela vhodnost takovéhoto „soudu“ na základě pocitů a bez elementárního právního povědomí, domnívám se však, že primárním smyslem bylo vyzdvihnout „špatnost“ jednání, a nikoli posuzovat jeho legálnost. Situace nicméně dobře ukazuje, že PO úlohy svojí mezioborovostí, a tedy nároky kladenými na mnohostrannost učitele, mohou svádět k prílišným zjednodušením.

23 Tak, jak byla vedena, úloha umožňovala více řešení, která ale v sobě měla omezení v podobě posouzení přiléhavosti, etičnosti apod. Úloha je rovněž jednoznačně mezioborového charakteru a navazuje tématem na prímou zkušenost žáků. 
Odlišný charakter interakce se odráží rovněž v prostředcích k udržování kázně. Protože je interakce volnější, působí jako její přerušení i prosté vyvolání. Mưžeme sledovat ale i běžné prostředky k získávání pozornosti jako tlesknutí, přiložení prstu na pusu, pokyn k hlášení, lusknutí prsty, ukázání na žáka (ukázka 2, ř. 29), k němuž chce učitel stáhnout pozornost (ukázka 2, ř. 19); nebo vrácením se do fiktivní role (např. ukázka 2, ř. 9). Řadíme sem rovněž prostředky k napomínání - ukázání, pohled; skrze ironické poukázání na nežádoucí chování žáka zopakováním jeho scestné odpovědi, kterou by jinak učitel pominul (ukázka 2, ř. 11-13) apod. Pokud se interakce nevymkne z institucionálních pravidel (viz výše) a žáci se nezačnou překřikovat, nechávají učitelé takovou interakci proběhnout, aniž by do ní zasahovali, a pouze ji zakončí komentářem, jenž ji shrne, doplní nebo poopraví (např. ukázka 1, ř. 37-48).

\subsection{Role učitele}

Oba učitelovy tahy v interakci - to, jakým způsobem zadává (pod)úlohu (typicky I-tah), i to, jak dává žákům zpětnou vazbu (F-tah), silně ovlivňují, jaké kognitivní procesy žáci při řešení používají, jak se zapojují i jak se učí uvažovat či pracovat (metakognitivní dovednosti). To vše v problémově orientované výuce platí dvojnásob, nebot' z principu je $v$ ní těžiště přeneseno z učitele na žáka a učitelova role je ještě více posunuta k usměrňování jeho myšlení či konání. F-tah může mít podobu jak zpětné vazby (feedback) užívané k hodnocení (pozitivnímu či negativnímu), tak follow-up - k prrimé pomoci s řešením úlohy nebo ke strukturování znalostí, které s úlohou souvisejí, což může žákům pomoci v dalším řešení nebo v usazení do kontextu. Podstatným rysem je, že učitel nechává žáky odpověd' konstruovat samostatně, a pokud žáci konstruktivně (rozuměj k tématu a v dialogu) diskutují, do interakce prakticky nevstupuje (jako v ukázce 1, ř. 38-45). Jeho role se projevuje ve chvíli, kdy je potřeba žáky nějakým způsobem zkorigovat/nasměrovat, což se děje, jak je vidět i v ukázce 2 , někdy i využitím ironie, jejíž vhodnost je diskutabilní. Popíšeme si tuto učitelovu roli v logice fází řešení.

\subsubsection{Při zadávání problémově orientované úlohy}

Iniciace má obvykle podobu zadání problémově orientované úlohy učitelem - až na výjimky, kdy pokládá problémovou úlohu žák (i ten tak činí po vyvolání učitelem). Jak už bylo řečeno, zadání je neadresné, často následované kontrolou porozumění, které je nutným předpokladem pro další relativně samostatné řešení (ukázka 2, ř. 6), a př́padným dovysvětlením pojmů spojených se zadáním (U: Vy si zahrajete na antropology, což jsou lidi, kteři se zajímají o původ a vývoj člověka. - CS13). Nezřídka učitel hned na začátku interakce parafrázuje iniciační otázku, přičemž se Ize domnívat, že tím nejen formuluje zadání různými způsoby, ale i prodlužuje čas na přemýšlení, což se projevuje tím, že se poté hlásí mnohem více žáků, než je jinak v hodině běžné. Při zpřesňování zadání samostatné práce (řešení úlohy) učitelé často zužují problémový prostor ve smyslu omezení počtu možných cest vedoucích $\mathrm{k}$ řešení $\checkmark$ reakci na repliky žáků. Lze se domnívat, že to souvisí se snahou nenechat žáky 
64 ztratit v podúlohách, snad i s úsporou času, nebot' čisté řešení PO úlohy - zcela bez učitelovy pomoci - by bylo dosti časově náročné a zatěžující. Př́íkladem může být rada, jak začít, nebo zaměření na prostředek $\mathrm{k}$ řešení (U: Můžeš srovnávat, můžeš napsat, co je úplně jinačí a co třeba nemá vůbec nikdo jiný v té živočišné říši. CS13), potvrzení žákem zvolené cesty řešení, konkretizace chyby nebo využití zužujícího podnětu k usměrnění interakce, která se př́liš rozvolnila (např. v ukázce 2 , ř. 15), či nabádání k použití určitého materiálu/zdroje informací (jako v situaci AS4, v níž učitel prstem obtahuje na obrázku tvar těla, čímž modeluje způsob uvažování nad řešením úlohy - a co se také odrazí na první odpovědi nebo listováním v knize v situaci AS1).

Během řešení PO úlohy učitel udržuje žáky při tématu, nebot' komplexnost těchto úloh či jednotlivé jejich podúlohy mohou zapřičinit odbočení od řešení, vedoucí dokonce až k opomenutí jejich vyřešení. Toho dosahuje jednak tím, že v reakci na odbíhání od tématu zopakuje nebo parafrázuje pưvodní otázku, nebo tím, že scestné odpovědi nereflektuje - U: Vy jste policisté, co s tím budete dělat? Z: Zabít. ((Učitelka nereaguje a vyvolává dalšího žáka.)) - AS7 -, pakliže pomocí nich nechce na něco poukázat (ukázka 1, ř. 24 a 2624). Udržování při tématu provádí učitel i skrze nápovědy a rady (viz níže).

\subsubsection{Zužování problémového prostoru}

U řešení PO úlohy je obzvláště dưležité, jak učitel s žáky (nebo žáci samostatně) elaborují řešení, nebot' tyto úlohy vyžadují řešení, která jsou komplexní, často jich je více správných nebo $k$ nim vedou různé cesty a vyžadují obvykle vyřešení několika podúloh nebo složení znalostí z více kontextů. Způsob, jakým na tyto aspekty učitelé žáky při řešení PO úlohy navádějí, se od běžného řešení liší v tom, že žákủm neradí otázkou přímo, ale spiše jim ukazují, jak přemýšlet, jaké procesy použít, které kontexty vzít v úvahu apod. Důležité je upozornit, že žákům neradí víc, než je potřeba, spiše zopakují či zdůrazní již řečené, co je podstatné.

Takovými otázkami postupně zužuje problémový prostor, a zaostřuje tak přemýšlení žáků určitým směrem - např. v situaci AS1, v níž je nejdříve otázka obecná, následuje otázka po zdůvodnění a třetí otázkou se posune ke konkrétnímu jevu: Myslíte si, jak kluci říkali, že v Japonsku jsou kapři, myslíte si, že ty ryby všeobecně ted'ka tam, co je velmi $v$ blízkosti té elektrárny, kde je ta silná radiace, myslíte si, že ty ryby se mohou lovit a jíst? - A co by se nám asi tak stalo, víme to? - Ale víme, co to znamená, my $v 5$. tř́dě, že jsou radioaktivní, co by nám to asi udělalo? Redukci možností, kterými se ubírat, lze provést i upozorněním na klíčový fakt z žákovy odpovědi, který je vhodné vzít v úvahu (U: Takže jak do sebe dostává ten kouř kuřák? - CS20, nebo U: Protože $v$ tom mateřském mléce...? - ES27), zaměřením na proces, kterým řešit úlohu (srovnání, hledání souvislostí, důsledkủ... - např. U: Anebo co dělávali s masem běžně předtím?, když vede žáky $\mathrm{k}$ úvahám nad možnostmi uchování a zpracování masa v pravěku a k souvislosti s ohněm - CS14, nebo U: To je

24 Zde jde sice o odpověd' správnou, ale na jinou otázku, nebot' $U$ se v ukázce 1 na ř. 7 a následně 15 , resp. 18 a 19 táže na důsledky vzpř́meného pohybu. 
všechno pravda. Ale v rámci toho zemědělství, tak se děje co. Když máme i dneska zemědělství, to víte z vlastivědy. (3) Tak co dělám? - CS14), radou, kde začít s řešením, at' už u které informace ( $S$ čím byste to dali dohromady? Dva bodíky $k$ tomu jdou tak hezky - CS13, když přemýšlejí nad odlišnostmi člověka a opic a jejich důsledky), nebo kde ve zdroji informací/materiálu (Tak si to tady přečti. - DS23), popř. na co zaměřit pozornost (kupř. když prstem obtahuje těla ryb při otázce směřující na rozdíly mezi kaprem a štikou v situaci AS4). Tyto prostředky (např. ukazováním, jak (ze s informacemi/zdroji nakládat a jak hledat řešení na zdánlivě neřešitelnou věc) mohou při jejich zvědomění napomoci v rozvíjení metakognitivních dovedností žáků.

\subsection{3 Řazení získaných znalostí do kontextů}

Dalším významným prostředkem, který učitelé při napovídání žákům během řešení PO úlohy uplatňují, nebot' tyto úlohy jsou z podstaty většinou mezioborového rázu, je využívání dalších kontextů - a to bud' pomocí srovnávání (např. v situaci AS4, kde upozorňuje na rozdíl mezi kaprem a štikou - v potravě, a tudiž v důsledku i v podobě a v pohybu), nebo naznačením souvislostí s něčím žákům zjevně známým. To se děje dvojím způsobem. (a) Podotázkou, která téma/pojem usadí v systému již známých pojmů - U: Ted'ka ta inteligence souvisí s čím? (5) Kde na těle máme teda uloženou inteligenci? - žáci dlouhý čas (5 sekund) neodpovídali, proto dává návodnou otázku, která sice nesměřuje k odpovědi, ale k tomu, čeho se to týká - CS14. Další příklad je z hodiny AS4: Když žáci tápou v odpovídání, co žere kapr, a odpovídají velmi rozdílně, radí, co on na tom dně vyhledává? Jaký je žravec? Tím usazuje preferovanou potravu do kontextu a do systému kategorií. Zde je třeba upozornit, že na konkrétní slovo se doptávají učitelé napřič celým vzorkem „kvalitních“ PO výukových situací až teprve při opakované výzvě k zpřesnění. (b) Druhým způsobem, jak učitelé radí žákům s využitím kontextu problémové úlohy, je otázkou, kterou naopak rozšiří kontext - U: Věděli byste, kdo ještě jinačí, že to nemusí být ani lidoopi, nebo ani primáti, umí použít nějaký nástroj? - CS13 či Jak vưbec [lidé] přišli na to, že je fajn pečené maso? - CS14. Zajímavým jevem pak je nápověda napodobováním nebo předváděním jevu - např. když řeší důsledky vzpřímeného pohybu pro člověka a radí žákům pohybem rukou, na co se mají zaměřit, nebo když ukazují pohyb opic a člověka, aby žákům zvýraznili, v čem může být mezi člověkem a opicí rozdíl (ukázka 1 , ř. 27-30), když upozorňují pomocí špetky na opozici palce (ukázka 1, ř. 48), popř. když naznačují pohyb štiky, aby naznačili rychlý hladký pohyb (AS4).

Nakonec učitelé často žáky nalezené řešení rozvinou, poukážou na souvislosti a podobnosti s dalšími oblastmi či na důsledky, které z jevu plynou (jako např. v situaci CS20, v níž se upozorňuje na škodlivost cigaretového kouře i pro nekourrící), na rưzná vnímání či pojmenování téhož. Obvykle také dovysvětlí a upřesní odpovědi žáků (ukázka 1, ř. 7, 33 či 36), propojí je s dalšími kontexty (např. poukazuje-li na souvislosti tvaru těla štiky s lovem potravy - U: Co to zpưsobuje, co to znamená, když ona pluje? Z: Že je rychlejší. U: Že je rychlejší. (...) Kluci, neznáte takové cizí slovo, jak se tomu ř́ká, jaký má tvar těla? - AS4; nebo odkazuje-li na aerodynamiku u automobilů) prípadně odpovědi zobecní, srovnají či pomocí kontextu zdůvodní, 
66 proč odpověd' není správná (ukázka 2, ř. 38-40). Dalším způsobem navázání na žákovské odpovědi je vyvození nového pojmu skrze zexplicitnění (kupř. ukázka 1 , r. 50-55).

\subsubsection{Zpětná vazba}

Efektivní poskytování zpětné vazby je vedle výše zmíněných rad a nápověd jedním z nejdůležitějších prostředků, jimiž učitel určuje charakter interakce. Pozitivní zpětná vazba je typickým príkladem uzavírací části sekvence a je prováděna obvyklými prostředky známými z řešení běžných, i neproblémových úloh - např. zopakováním odpovědi žáka (ukázka 1, ř. 13), parafrází (ukázka 1, ř. 33), prostým uznáním správné odpovědi (ukázka 1, ř. 5), navázáním na žákovu (správnou) odpověd’ další otázkou (upřesňující či rozšiřující) či reformulováním žákovy relativně správné odpovědi, přičemž ji učitel poopraví tak, aby byla správně. Negativní zpětná vazba je nejčastěji provedena negací odpovědi (Z: Mohli bysme svitit jak žárovka.; U: To bysme teda nemohli svítit jak žárovka - AS1) nebo jejím převedením do tázací věty (Policisté se seberou a vyčistí rybník? - AS7), dále označením problému, a to bud' jasným (Ale tam je jiné slovo. - DS23), nebo rámcovým (Tam je, tady v té dvojce, tam je jiná odpověd', zkus si to prečíst pořádně. - DS23). Co je ale pro problémově orientovanou výuku charakteristické, je, že učitelé nereagují na žákovu špatnou odpověd' tím, že sami řeknou správnou. To je dáno konstruktivistickým pojetím výuky využívající PO úlohy, resp. PO výukové situace.

Dalším prostředkem, který má vliv na charakter interakce, a v souvislosti s ním i na to, jakou úroveň myšlení žáci zapojí (což není předmětem našeho zkoumání) a kdo a jak vlastně řeší PO úlohu, jsou otázky. Je nutné uvést, že nemíníme ty, které jsou zadáním PO úlohy, nýbrž ty, jimiž učitelé žákům pomáhají vyřešit PO úlohu. Základem jsou otázky, v nichž učitel elicituje (a) zpřesnění žákovy odpovědi - ptá se po dovysvětlení, prríčině, zdůvodnění, doplnění odpovědi nebo výběru podstatného proto jsou užívány věty typu: Kdo by to řekl nějak jinak? Jak to myslíš?, a zejména Proč?; a (b) více odpovědí a hledá více možných řešení, pro což jsou typické otázky: Co ještě? Má někdo jiné řešení? Proč ještě? (např. ukázka 1, ř. 15). Charakter PO úloh staví tedy učitele spiše než do role „toho, kdo zná odpověd'“ (primary knower srov. Nassaji \& Wells, 2000), do role toho, kdo koriguje žáky při hledání řešení; spiše než toho, kdo opraví odpověd', do role toho, kdo žáky přiměje k nalezení správné odpovědi; a spiše než toho, kdo se ptá konkrétně, do role toho, jenž radí v řešení co možná nejméně, a nechává tak co nejvíce prostoru pro přemýšlení žáků.

\section{Diskuse a závěry}

Problémově orientovaná výuka má svá specifika. Aby byla kvalitní, nestačí pouze ji „problémově“ zadat (což s sebou přináší i vysoké nároky na učitelovo posouzení dosavadních znalostí žáků i znalost oboru obecně). Řešení úlohy musí být vedené učitelem tak, aby rozvíjelo u žáků danou kompetenci (je tedy nutné sledovat ji v kontextu 
Tabulka 1 Charakteristiky řešení problémově orientované úlohy v kontextu problémově orientované výukové situace

\begin{tabular}{|c|c|c|c|c|c|}
\hline & $\begin{array}{c}\text { Triáda } \\
\text { (variace) }\end{array}$ & $\begin{array}{l}\text { Fáze PO } \\
\text { výukové } \\
\text { situace }\end{array}$ & Učitel & Žáci & Co je charakteristické \\
\hline $\begin{array}{l}\text { Zadání PO } \\
\text { úlohy }\end{array}$ & $\begin{array}{l}\text { Initiation } \\
\text { (I) }\end{array}$ & $\mathrm{F} 1$ & $\begin{array}{l}\text { - kontroluje } \\
\text { porozumění } \\
\text { - dovysvětluje }\end{array}$ & $\begin{array}{l}\text { - v príípadě } \\
\text { nejasností } \\
\text { se doptávají, } \\
\text { upřesňují }\end{array}$ & $\begin{array}{l}\text { Zadání úlohy je } \\
\text { (a) problémově orientované } \\
\text { (vyšší kognitivní náročnost, } \\
\text { komplexnější řešení, nutné } \\
\text { propojovat kontexty, } \\
\text { větší nároky na čas); } \\
\text { (b) neadresné. }\end{array}$ \\
\hline $\begin{array}{l}\text { Průběh } \\
\text { řešení }\end{array}$ & $\begin{array}{l}\text { Response } \\
\text { (R) }\end{array}$ & $\begin{array}{l}F 2, F 3, \\
F 4\end{array}$ & $\begin{array}{l}\text { - radí - zužuje } \\
\text { problémový } \\
\text { prostor } \\
\text { - vyzdvihuje pro } \\
\text { řešení podstatné } \\
\text { body či správné } \\
\text { úvahy žáků } \\
\text { - pomáhá - } \\
\text { paralelou } \\
\text { z jiného kontextu } \\
\text { - radí, kde začít } \\
\text { s řešením, } \\
\text { jaký proces } \\
\text { k řešení využít, } \\
\text { na co zaměřit } \\
\text { pozornost } \\
\text { - kontroluje kázeň } \\
\text { - udržuje žáky } \\
\text { u tématu (někdy } \\
\text { i pominutím } \\
\text { odpovědí, které } \\
\text { by mohly žáky } \\
\text { svést jinam) }\end{array}$ & $\begin{array}{l}\text { - konstruují } \\
\text { řešení } \\
\text { společně } \\
\text { - zapojují } \\
\text { znalosti } \\
\text { z jiných } \\
\text { oborů/ } \\
\text { kontextů } \\
\text { - spíše } \\
\text { diskuse, } \\
\text { žáci mohou } \\
\text { hovořit bez } \\
\text { vyvolání } \\
\text { a vzájemně } \\
\text { na sebe } \\
\text { reagují }\end{array}$ & $\begin{array}{l}\text { Učitel nevede žáky přímo } \\
\text { k řešení, nechává jim prostor } \\
\text { pro vlastní úvahy. } \\
\text { Žáci sami musejí přijít na kroky } \\
\text { nutné k řešení. } \\
\text { Institucionální pravidla jsou } \\
\text { volnější. } \\
\text { Aktivita je více na straně žáků, } \\
\text { učitel spíše usměrňuje diskusi, } \\
\text { neradí návodně, spíš ukazuje } \\
\text { směry uvažování a podněcuje } \\
\text { k dalšímu promýšlení; } \\
\text { konkrétní otázka navádějící } \\
\text { k řešení je až poslední } \\
\text { možností. }\end{array}$ \\
\hline $\begin{array}{l}\text { Odpověd'/ } \\
\text { řešení }\end{array}$ & $\begin{array}{l}\text { Follow-up } \\
\text { (F) }\end{array}$ & F2, F5 & $\begin{array}{l}\text { - elicituje } \\
\text { zpřesnění či } \\
\text { doplnění } \\
\text { - táže se po } \\
\text { obhájení/ } \\
\text { zdůvodnění/ } \\
\text { vysvětlení } \\
\text { odpovědi } \\
\text { - táže se po } \\
\text { dalších možných } \\
\text { řešeních }\end{array}$ & $\begin{array}{l}\text { - zdůvodňují, } \\
\text { zpřesňují, } \\
\text { doplňují, } \\
\text { vysvětlují, } \\
\text { obhajují } \\
\text { odpověd' } \\
\text { - hledají } \\
\text { další řešení }\end{array}$ & $\begin{array}{l}\text { Učitel neřeší úlohu za žáky } \\
\text { (ani po správném začátku } \\
\text { provedeném žáky), oprava } \\
\text { směřuje k dalšímu řešení } \\
\text { žáky, učitel neříká správnou } \\
\text { odpověd', ale přivádí k ní žáky. } \\
\text { Učiteli nestačí prostá odpověd' } \\
\text { a vyžaduje zdůvodnění, } \\
\text { vysvětlení. } \\
\text { Učiteli nestačí jedno správné } \\
\text { řešení, je-li jich možných více. } \\
\text { Nakonec učitel řešení shrne } \\
\text { a usadí do kontextu. }\end{array}$ \\
\hline
\end{tabular}


68 PO výukové situace, nikoliv izolovaně), a vzhledem $\mathrm{k}$ tomu, že se žáci mnohem lépe učí skrze vlastní bádání než předávanými fakty (viz např. Harlen \& Qualter, 2014), považujeme za důležité se věnovat tomu, jak tento způsob výuky může probíhat, a to na př́kladu PO výuky, která je na vlastním uvažování žáků nad jevy založena. Analýza procesů, které se při interakci během řešení PO učebních úloh odehrávají, poodhalila, jak učitel v dialogu s žáky konstruuje řešení PO úlohy. Tabulka 1 shrnuje zkoumaný jev podrobněji. Celý proces je vlastně volnou variací na triádu IRF (jakkoli jsem si vědoma, že $v$ jedné každé fázi probíhá nějaká podoba triadické interakce sama o sobě $v$ podobě, o niž hovoříme $v$ úvodní části). Řečeno paralelou iniciace při řešení PO úlohy spočívá v zadání problémově orientované úlohy, jež z hlediska fází problémově orientované výukové situace (podrobněji viz Češková, 2016; Češková \& Knecht, 2016) odpovídá fázi F1 (iniciování PO úlohy). Průběh řešení je variantou R-tahu, odpovědi, a koresponduje s fázemi F2 (analyzování problému), F3 (hledání informací) a F4 (syntetizování řešení). V pojetí odpovědi na PO úlohu můžeme vidět paralelu v F-tahu, nebot' odpověd' je dále dopracovávána, rozvíjena, usazena do kontextu. Prolíná se zde tedy sumarizace a usazení do kontextu (F5) a analyzování (F2) při hledání vysvětlení, zdůvodnění, dalších řešení apod.

Při bližším pohledu na sledované interakce je zjevná blízkost ke konceptu scaffoldingu ${ }^{25}$, jakkoli ten je orientován více na proces, tedy na to, jakými způsoby úlohu řešit. V programovém textu popisují Wood, Bruner a Rossová (1976) šest funkcí učitele

25 Scaffolding definují např. Petrová a Pupala (2008, s. 121) jako „jakoukoliv intervenční interakci tutora vztahující se k osvojení si zručností a řešení problémů učícím se jedincem, která umožní dítěti řešit problém, vykonat úlohu nebo dosáhnout cíle navzdory tomu, že nedisponuje dostatečnými zkušenostmi na jejich samostatné zvládnuti““. Učitelova práce spočívá v motivaci; redukci svobody spočivající v zúžení problémového prostoru (problem space) a počtu možných relevantních proměnných; „vyvádění ze slepých uliček“; zdůrazňování a oceňování správných kroků; kontrolování obtížnosti problému tak, aby byla zvladatelná, avšak ne snadná; a navození žádoucího řešení (Wood et al., 1976, s. 98). Je zjevné, že scaffolding, jak byl definován v pracích zmíněných $v$ předchozím odstavci (zejm. Woodem et al., 1976), je pojímán jako interakce mezi tutorem (učitelem) a žákem, přičemž učitel reaguje na aktuální porozumění konkrétního žáka, které skrze sociální interakci rozvíjí, a je tedy zřejmá jeho souvislost s Vygotského zónou nejbližšího rozvoje. V mnoha studiích (viz níže) je však scaffolding často chápán jako výuková strategie, která propojuje funkce a principy scaffoldingu v pưvodním pojetí, ale zároveň opomíjí aspekt toho, že učitel reaguje na konkrétního žáka - cílem je totiž tzv. sdílené porozumění v celé trídě (Puntambekar \& Hübscher, 2005, s. 2-3). Někteří autoři tuto podobu dokonce nenazývají scaffoldingem (např. Koole \& Elbers, 2014) a tvrdí, že jde pouze o prostředky elicitování odpovědí od žákủ (např. Myhill \& Warren, 2005). Jak vysvětluje Stone (1998), ve slovenštině pak s odlišnými východisky shrnují Petrová a Pupala (2008), scaffolding (coby výuková strategie) je jednou z interpretací Vygotského myšlenek, která původní metaforu posouvá do jiného teoretického kontextu: zatímco Vygotskij ve své ZNV míŕi na rozvíjení kognitivních procesů, resp. psychických funkcí, které jsou rozvinuté nedostatečně pro samostatné jednání jedince, ale zároveň jsou dostatečnou oporou pro jednání s pomocí kompetentnějšího druhého - řeší tedy žákův kognitivní rozvoj skrze sociální interakci; „lešeni" se více soustředí na podobu oné pomoci (na mikroúroveň, ne na sociokulturní kontext), na formu a průběh interakce mezi ( $v$ našem případě) žákem a učitelem, jež je navíc vedena učitelem zejména za účelem rozvíjení žákových znalostí a dovedností. Já se budu dále věnovat pouze scaffoldingu ve smyslu výukové strategie, tedy tomu, jak, jakými prostředky učitel působí na žáky během ( $v$ našem případě problémově orientované) výukové situace, a to s vědomím toho, že jde o interpretaci posunutou od pưvodního konceptu, která však otevřeně využívá některých pưvodních principů. 
během scaffoldingu - motivace, redukce stupně svobody, „udržování směru“, značení důležitých prvků v řešení, kontrola frustrace a demonstrování nebo modelování -, zatímco naše analýza ukázala vedle těchto charakteristik ještě druhou dominantní oblast - zaměření na to, jaké dosavadní znalosti použít k vyřešení PO úlohy. Protože konverzační analýza z podstaty nemǔže postihnout záměry (intentions), na nichž naopak scaffolding staví, a nemohla jsem proto scaffolding kvưli paradigmatickému střetu brát v úvahu při vlastní analýze, uvedu jej jako základní rámec pro diskusi.

Specifičnost interakcí při řešení PO úlohy se nejvíce projevuje $v$ organizačním rádu, ve formě zpětné vazby, nápověd či rad a skrze různé typy dotazování (i proto vše diskutujeme se scaffoldingem, jenž je $v$ těchto intencích poměrně hojně rozpracováván - viz např. Tharp \& Gallimore, 1988). Obecně řečeno, je dán mnohem větší důraz na aktivní zapojení žáků, což s sebou nese změny $v$ organizaci interakce. Ve sledovaných situacích lze pozorovat $v$ teorii (viz výše) popisovanou záměrnou práci s pauzami mezi promluvami. To je sice jevem běžným pro výuku obecně, nicméně v problémově orientované výuce je dán žákům mnohem větší prostor samostatnému řešení, které je navíc nutné elaborovat. Proto se jeví jako důležité, když učitelé poskytují žákům delší čas na promýšlení odpovědi. Delší pauza v replice, již učitel využívá k tomu, aby poskytl žákům čas na přemýšlení nebo formulování odpovědi, může zvyšovat kvalitu žákovských odpovědí (viz např. Maroni, 2011). Navíc se potvrzují výzkumy (viz kupř. Rowe, 1986; Tobin, 1987; Kirton et al., 2007; Ingram \& Elliott, 2016), které uvádějí, že délka času poskytnutého žákům na promyšlení odpovědi min. 3 sekundy, pokud je ovšem otázka dostatečně (úměrně) obtížná a vykazuje vyšší kognitivní náročnost, má vliv na odpovědi žáků, a to jak z hlediska množství studentů, již jsou ochotni odpovídat, tak délky, propracovanosti a správnosti i množství alternativ. Tobinova metaanalýza (1987) prokázala rovněž vliv na větší vzájemné naslouchání mezi žáky a méně vyrušování. Roweová (1986) pak upozorňuje, že dávají-li učitelé žákům delší čas na přemýšlení, dělají pak i oni méně chyb a více reflektují žákovské odpovědi.

Tím, že žáci ve sledované výuce reagují na sebe navzájem, se vlastně narušuje jedno ze základních pravidel školní interakce - že jediný, kdo může vybrat jiného mluvčího, je učitel. Pokud učitel ale nikoho nenominuje (nevyvolá), dává k tomu vlastně svolení a toleruje, že odpovědí (R) může být víc, že odpověd' jednoho žáka podporuje, doplňuje, nebo naopak iniciuje opravu či prrímo opravuje jiný žák apod. Vzájemná reaktivita žáků je v PO přístupu podporována (čímž se jich do diskuse zapojuje i více - srov. Tobin, 1987). To podporuje svými závěry i Fisher (2007), jenž tvrdí, že naslouchání a reagování žáků navzájem je klíčem $k$ úspěšnému řešení problémových úloh. Tobin et al. (2013) pak ve své studii ukazují, že tento typ interakce (méně učitelem řízená diskuse, v ní̌ žáci reagují na sebe navzájem) je spojen s pozitivním emočním klimatem ve tř́dě.

Výuka tak probíhá spiše jako diskuse. Chinová (2006) o této podobě interakce hovoří jako o guided discussion, v níz učitel otázkami směřujícími na konceptuální znalosti elicituje produktivní myšlení. McMahonová (2012) pak zdůrazňuje, že v tomto typu interakce spiše než o identifikování a rozvíjení žákovských prekonceptů či 
70 potenciálních miskoncepců jde o sdílené promýšlení - interthinking, v němž je cílem vzájemné porozumění a společné konstruování znalostí, kdy preferovanou strategií je hledání a ověřování žákovských řešení. Do této „diskuse“ učitel zasahuje ve třech prípadech: za prvé tehdy, chce-li něco dovysvětlit, na něco $z$ odpovědi žáků upozornit, opravit, upoutat jejich pozornost určitým směrem apod. Zde se projevuje i Knechtem (2014) pojmenované klasické didaktické dilema učitele - jak žákưm říci a zároveň neříci, jak mají úlohu vyřešit - a reflektuje to dobře i funkci scaffoldingu, totiž jak naznačit, kudy dál, ale neprozradit více, než je nezbytně nutné.

Druhou situací, kdy v námi sledované výuce učitel vstupuje do diskuse, je, pokud chce žáky někam nasměrovat, nejčastěji zpět $k$ tématu. Tento fakt reflektuje $v$ souvislosti s dialogickým vyučováním Mercer et al. (2004, s. 361) s tím, že mají-li žáci diskutovat ve skupině, často nevědí, jak - což je přirozené, nebot' jen málokdy mají príležitost setkat se v běžném životě s konstruktivní diskusí, a učitel obvykle neřekne, jak má taková diskuse probíhat. To pak vede k odbíhání od úlohy, neefektivnímu a neproduktivnímu dohadování se apod. Žáci, na 1. stupni zvlášt', tedy potřebují osnovu, návodnou instrukci, co diskutovat, musejí znát a ctít pravidla diskuse atp. V našem prostředí je, jak uvádí rovněž studie TIMSS 1999, typické společné řešení PO úlohy, při němž učitel vede interakci, a zabraňuje tak sklouznout mimo téma (viz Roth et al., 2006). Ani zde se tedy výsledky neliší od dalších výzkumů.

Třetím typem situace, kdy učitel $v$ interakci při řešení PO úloh zasáhne, je, pokud se diskuse vymkne $z$ pořádku a žáci se překřikují, aniž by to mělo nějaký rád. V takové chvíli vyučující obvykle adresně vyvolá nějakého žáka, čímž zkoncentruje pozornost ostatních, a navíc získá opět kontrolu nad interakcí - McHoul (1978, s. 199) tento jev nazývá „normalizace jednání jako reparativní technika“. Vzhledem $\mathrm{k}$ tomu, že jde o diskusi ř́zenou učitelem, i v problémově orientované výuce se jedná o střední typ komunikace - na rozdíl od běžné, frontální výuky neproblémového charakteru, již bychom řadili spíše k one-turn-at-time allocation (Sacks et al., 1974, s. 729), nebot' je dána pevně IRF strukturou a učitel určuje vždy dalšího mluvčího.

Chce-li učitel žákům při řešení nějak poradit, nejčastěji to udělá zredukováním problémového prostoru. To se zdá výsledkem kontinuálního diagnostikování, nebot', stejně jako při scaffoldingu, který spiš hledá stupeň svobody ve volbě řešení, učitel neradí pomocí předem promyšlených nápověd, ale $v$ závislosti na tom, jak žáci aktuálně pracují, na jejich projevené (tedy nikoli předpokládané) znalosti a na jejich uvažování, které ale dají najevo (jak to popisují rovněž i Koole \& Elbers, 2014). Pakliže nechtějí prozradit řešení, jeví se nápověda skrze snížení počtu možných operací, jež lze užít k řešení, nebo upozorněním na klíčové informace $z$ předchozí odpovědi jako nejpřímější cesta, kdy ještě radí, ale neřeši úlohu za žáky.

Zatímco nejběžnější podobou interakce učitele se třídou obecně je IRF (a to i v českém prostředí - viz Šed'ová et al., 2011), nebot' obvykle učitel položí otázku, žák odpoví, učitel ji zhodnotí a položí další otázku..., a zpětná vazba v neproblémové výuce je tak mnohem více sumativní (Nassaji \& Wells, 2000), v těch hodinách ze zkoumaného vzorku, kde žáci dostali velký prostor $k$ samostatnému řešení PO úlohy (typicky hodiny učitele $\mathrm{C}$ ), je struktura řešení PO úlohy většinou $v$ nějaké 
variantě IRFRF, tedy $v$ podobě, která zohledňuje potřebu větší elaborace řešení.

Tato struktura je podle Mortimera a Scotta (2003) řetězcem typickým pro dialogické/interaktivní vyučování, daný způsob vedení výuky pak označují jako vhodný pro objevování, hledání různých úhlů pohledu, vytváření nových významů, vazeb a jejich zařazování do kontextu. Viděno touto optikou se nelze častému výskytu IRFRF struktury při řešení PO úloh, jež ke zmíněným charakteristikám inklinují, divit. Protože musí žáci kvưli komplexnosti úlohy odpovědi více elaborovat, pouhé zhodnocení jejich (ne)správnosti nestačí, a zpětná vazba učitele je tak mnohem více formativní a poskytuje „lešení“ k tomu, aby žák dané řešení rozvedl, zpřesnil, přidal další atp. To, že sekvenci vždy, at' už ji iniciuje žák, nebo učitel otázkou, a at' už F-krok provádí žák, či učitel, uzavírá učitel, komentují Nassaji a Wells (2000, s. 378) tím, že učitel tak plní svoji roli facilitátora (či manažera). Muhonenová et al. (2016) pak tento typ interakce pojmenovávají jako dialog iniciovaný učitelem, který je vysoké kvality, sestává obvykle z menšího množství většinou otevřených otázek blízkých každodennímu životu a žákovským zkušenostem, což přispívá dle autorek k volnější diskusi. Tím se naši zkoumaní učitelé přirozeně odlišují např. od zjištění Knechta (2014), jenž konstatoval, že učitelé místo podpory žáků v řešení často vyřeší problémově orientované úlohy de facto sami. To je dáno samožrejmě naším výběrem (kvalitních, rozvíjejících) situací, nicméně to poukazuje na fakt, že pokud učitelé rozšiřovali, objasňovali a shrnovali své i žákovské nápady a podporovali žáky ve sdílení odlišných názorů, poměr žákovské řeči a řeči učitele byl vyrovnanější a potenciál rozvíjení kompetence $\mathrm{k}$ řešení problémů u žáků tím pádem vyšší. Obdobně jako ve výzkumu Nassaji a Wellse (2000) učitelé, u nichž byly analyzovány potenciálně kvalitní výukové situace, používají učitelé popisovaní v této studii F-tah spíše než ke zhodnocení správnosti k posouzení relevantnosti odpovědi pro řešení, popř. zdůrazňují podstatnou informaci pro dalši řešení nebo navádí k dalšímu řešení.

Kromě významných rozdílů ve vedení interakce učitel zpětnou vazbu využívá nejčastěji k práci s dalšími kontexty prostřednictvím rad a nápověd nebo k vysvětlování. I s tímto konceptem pracuje scaffolding v podobě kognitivního strukturování (Tharp \& Gallimore, 1988). Jeho využívání označuje Fisher (2007) jako kognitivní výzvu a je to považováno za nejkomplexnější prostředek scaffoldingu (Tharp \& Gallimore, 1988). Jeho důležitost dle nás ale spočívá v tom, že nejvíce propojuje rozvíjení klíčových kompetencí a obsahu (oboru).

Naopak ve srovnání se scaffoldingem bylo překvapivé malé využití modelování ve sledovaných situacích, nebot' např. metaanalýza Van de Polové, Volmanové a Beishuizena (2010) ukazuje právě tento prostředek scaffoldingu jako nejvíce zastoupený napříč různými předměty na 1. a 2. stupni, a to spolu s dotazováním se. Naproti tomu zkoumaní učitelé využívali násobně více nápověd a rad, což by mohlo být dáno diskusním charakterem české výuky přírodovědy, jaký zmiňovala i studie TIMSS 1999 (Roth et al., 2006).

Klíčové postavení v celém procesu má učitelovo dotazování se. Je zjevné, že není používáno pouze jako zadání úlohy, ale je součástí neustálého diagnostikování, formou zapojování žáků do diskuse i podporování myšlení žáků. Pro učitele je typické 
72 zjišt’ování více odpovědí na tutéž otázku, doptávání se, ptaní se po dovysvětlení atp. To koresponduje s nálezy Chinové (2006), která řadí doptávání se s cílem získat více odpovědí, navádění na jiné způsoby uvažování, otázky ukazující na další kontext, na zaměření pozornosti určitým směrem atp. mezi př́stupy, které efektivně rozvíjejí produktivní myšlení u žáků. Stejně jako u Woodové, Williamsové a McNealové (2006), jejichž analýza ukázala, že při řešení problémových úloh kladli sledovaní učitelé důraz na argumentaci žáků (autoři to nazývají reform instruction) - na rozdíl od běžné (autory nazývané konvenční) interakce při řešení úloh z učebnice, v níž dominovaly nápovědy učitele směřující ke způsobu řešení (hint to solution), i v námi sledovaných situacích měla zásadní postavení otázka: Proč?, jež v sobě odráží princip problémově orientované výuky (soustředící se na souvislosti, procedurální znalosti atp.) a současně vlastně i princip scaffoldingu (pomoci v uvažování, nasměrovat). To je, jak uvádí Hmelo-Silverová (2006, s. 154), hlavní devízou scaffoldingu - nejen najít cestu, jak vyřešit úlohu, ale také podporovat u žáků artikulaci myšlenek i argumentaci, a zviditelňovat/zexplicitňovat tak jejich myšlenkové procesy. U sledovaných interakcí během řešení problémově orientovaných úloh se tak otázka Proč? často ukazuje být „meritem věci“ nejen jako jedna ze základních variant zadání problémově orientované úlohy, ale i při jejím řešení.

Přestože by bylo chybné tvrdit, že běžná, v tomto př́padě neproblémově orientovaná, výuka nevyužívá mnohé z popisovaných prvků, ukázala předložená analýza na některá specifika, mj. odlišnou roli učitele, který musí mnohem více vytvářet príležitosti pro to, aby se žáci aktivně, $v$ co nejvyšší míre, a ještě navíc pokud možno efektivně na řešení takových úloh podíleli. Zaměření na interakci u výukových situací, které jsou potenciálně kvalitnější, může pomoci pochopit, jak při řešení takovýchto PO výukových situací, jež jsou díky své „problémovosti“ do jisté míry specifické, postupovat. I zde se však ukázalo, že sledovat pouze formu a nezohledňovat obsah, na kterém se odehrává, by naše poznání dovedlo do pomýlených cest stejně, jak to shledávají ve svém výzkumu zaměřeném na účelnost $v$ dialogickém vyučování Šalamounová a kol. (2012).

Dalším krokem bude podrobná analýza výukových situací, které byly sice založeny na problémově orientované úloze, jejich realizace však v některých krocích selhala, a nenaplnily tak dostatečně potenciál, který pro rozvíjení dané kompetence měly. Proto bylo ale potřebné udělat první krok, a to podrobně popsat, jak vypadají interakce v situacích potenciálně kvalitních. Ověření, zda je uvedený zpưsob rozvíjení kompetence $\mathrm{k}$ řešení problémů skutečně efektivní, by bylo ovšem možné pouze měřením výsledkủ žáků, a to by si jistě zasloužilo samostatný výzkum. Takto musíme věrit tomu, že je-li prokázána efektivita problémového vyučování a učení a máme-li popsány interakce při řešení potenciálně kvalitnějších problémově orientovaných situací, bude jejich kombinace, na kterou jsem se v tomto článku zaměřila, mít rovněž pozitivní efekt. 


\section{Poděkování}

Studie vznikla za podpory projektu Výzkum edukačních procesů, podmínek a prostředků (MUNI/A/1244/2016). Děkuji doc. Františku Tůmovi za podporu a cenné rady při využití konverzační analýzy, doc. Petru Najvarovi za četné konzultace a také oběma recenzentům, jejichž podněty pomohly text výrazně posunout, projasnit a zpřehlednit.

\section{Literatura}

Alexander, R. J. (2005). Teaching through dialogue: The first year. London: London Borough of Barking and Dagenham.

Cohen, L., Manion, L., \& Morrison, K. (2011). Research methods in education. Abingdon: Routledge.

Češková, T. (2016). Výukové situace rozvíjející kompetenci k řešení problémů: teoretický model jako východisko pro jejich analýzu. Pedagogika, 66(5), 530-548.

Češková, T., \& Knecht, P. (2016). Analýza problémově orientovaných výukových situací ve výuce prírodovědy. Orbis scholae, 10(2), 93-115.

Fisher, R. (2007). Dialogic teaching: Developing thinking and metacognition through philosophical discussion. Early Child Development and Care, 177(6-7), 615-631.

Gaut, B. (2000). „Art“ as a cluster concept. In N. Carroll (Ed.), Theories of art today (s. 25-44). Madison: University of Wisconsin Press.

Gavora, P. (2005). Učitel a žáci v komunikaci. Brno: Paido.

Goodwin, C., \& Heritage, J. (1990). Conversation analysis. Annual Review of Anthropology, 19(1), 283-307.

Harlen, W., \& Qualter, A. (2014). The teaching of science in primary schools. London: Routledge. Havlík, M. (2012). Sekvenční a prozodické aspekty rozhovoru (Disertační práce). Praha: FF UK. Hmelo-Silver, C. E. (2006). Design principles for scaffolding technology-based inquiry. In A. M. O’Donnell, C. E. Hmelo-Silver, \& G. Erkens (Eds.), Collaborative reasoning, learning and technology (s. 147-170). Mahwah: Erlbaum.

Chi, M. T. H., \& Glaser, R. (1985). Problem-solving ability. In R. J. Sternberg (Ed.), Human abilities: An information-processing approach (s. 227-250). New York: Freedman.

Chin, C. (2006). Classroom interaction in science: Teacher questioning and feedback to students' responses. International Journal of Science Education, 28(11), 1315-1346.

Ingram, J., \& Elliott, V. (2014). Turn taking and „wait time“ in classroom interactions. Journal of Pragmatics, 62, 1-12.

Ingram, J., \& Elliott, V. (2016). A critical analysis of the role of wait time in classroom interactions and the effects on student and teacher interactional behaviours. Cambridge Journal of Education, 46(1), 37-53.

Ingram, J., Pitt, A., \& Baldry, F. (2015). Handling errors as they arise in whole-class interactions. Research in Mathematics Education, 17(3), 183-197.

Janík, T., Slavík, J., Mužík, V., Trna, J., Janko, T., Lokajíčková, V., ... Šebestová, S. (2013). Kvalita (ve) vzdělávání: obsahově zaměřený přistup ke zkoumání a zlepšování výuky. Brno: MU.

Jonassen, D. H. (1997). Instructional design model for well-structured and ill-structured problem-solving learning outcomes. Educational Technology: Research and Development, 45(1), 65-95.

Kirton, A., Hallam, S., Peffers, J., Robertson, P., \& Stobart, G. (2007). Revolution, evolution or a Trojan horse? Piloting assessment for learning in some Scottish primary schools. British Educational Research Journal, 33(4), 605-627. 
74 Klieme, E., Schümer, G., \& Knoll, S. (2001). Mathematikunterricht in der Sekundarstufe I: Aufgabenkultur und Unterrichtsgestaltung. In E. Klieme \& J. Baumert (Eds.), TIMSS-Impulse für Schule und Unterricht (s. 43-57). Bonn: Bundesministerium für Bildung und Forschung. Knecht, P. (2007). Didaktická transformace aneb Od „didaktického zjednodušení“ k „didaktické rekonstrukci“. Orbis scholae, 2(1), 67-81.

Knecht, P. (2014). Příležitosti k rozvíjení kompetence $k$ řešení problémů $v$ učebnicích a ve výuce zeměpisu. Brno: MU.

Konečná, M. (2007). Řeč a rozumění: poznámky k filosofické a teologické hermeneutice H.-G. Gadamera, G. Ebelinga a E. Fuchse. Brno: Marek Konečný.

Koole, T., \& Elbers, E. (2014). Responsiveness in teacher explanations: A conversation analytical perspective on scaffolding. Linguistics and Education, 26, 57-69.

Lee, Y. A. (2007). Third turn position in teacher talk: Contingency and the work of teaching. Journal of Pragmatics, 39(6), 1204-1230.

Lemke, J. L. (1990). Talking science: Language, learning, and values. Chestnut Street: Ablex Publishing Corporation.

Maloney, J., \& Simon, S. (2006). Mapping children's discussions of evidence in science to assess collaboration and argumentation. International Journal of Science Education, 28(15), 1817-1841.

Mareš, J. (2016). Pro výzkumy komunikačních struktur ve výuce neplatí: Jak prosté, milý Watsone! Pedagogika, 56(3), 344-353.

Mareš, J., \& Křivohlavý, J. (1995). Komunikace ve škole. Brno: MU.

Markee, N. (2015). The handbook of classroom discourse and interaction. Hoboken: John Wiley \& Sons.

Maroni, B. (2011). Pauses, gaps and wait time in classroom interaction in primary schools. Journal of Pragmatics, 43(7), 2081-2093.

Maxwell, J. A. (2010). Validity: How might you be wrong. In W. Luttrell (Ed.), Qualitative educational research: Readings in reflexive methodology and transformative practice (s. 279-287). New York: Routledge.

McHoul, A. (1978). The organization of turns at formal talk in the classroom. Language in Society, 7(2), 183-213.

McMahon, K. (2012). Case studies of interactive whole-class teaching in primary science: Communicative approach and pedagogic purposes. International Journal of Science Education, 34(11), 1687-1708.

Mehan, H. (1979). Learning lessons. Cambridge: Harvard University Press.

Mercer, N., Dawes, L., Wegerif, R., \& Sams, C. (2004). Reasoning as a scientist: Ways of helping children to use language to learn science. British Educational Research Journal, 30(3), 359-377.

Mortimer, E., \& Scott, P. (2003). Meaning making in secondary science classrooms. Berkshire: McGraw-Hill Education.

Muhonen, H., Rasku-Puttonen, H., Pakarinen, E., Poikkeus, A. M., \& Lerkkanen, M. K. (2016). Scaffolding through dialogic teaching in early school classrooms. Teaching and Teacher Education, 55, 143-154.

Myhill, D., \& Warren, P. (2005). Scaffolds or straitjackets? Critical moments in classroom discourse. Educational Review, 57(1), 55-69.

Nassaji, H., \& Wells, G. (2000). What's the use of „triadic dialogue“?: An investigation of teacher-student interaction. Applied Linguistics, 21(3), 376-406.

Nomlomo, V. (2010). Classroom interaction: Turn-taking as a pedagogical strategy. Per Linguam: a Journal of Language Learning / Per Linguam: Tydskrif vir Taalaanleer, 26(2), 50-66.

Nystrand, M., Wu, L. L., Gamoran, A., Zeiser, S., \& Long, D. A. (2003). Questions in time: Investigating the structure and dynamics of unfolding classroom discourse. Discourse Processes, 35(2), 135-198.

Petrová, Z., \& Pupala, B. (2008). K súčasným pedagogickým diskusiám o zóne najbližšieho vývinu. Pedagogika, 58(2), 117-130. 
Píšová, M., Hanušová, S., Kostková, K., Janíková, V., Najvar, P., \& Tůma, F. (2013). Učitel expert: jeho charakteristiky a determinanty profesního rozvoje (na pozadí výuky cizích jazyků). Brno: MU.

Puntambekar, S., \& Hübscher, R. (2005). Tools for scaffolding students in a complex learning environment: What have we gained and what have we missed? Educational Psychologist, 40(1), 1-12.

Rámcový vzdělávací program pro základní vzdělávání (2005). Praha: NúV.

Rámcový vzdělávací program pro základní vzdělávání (2016). Praha: NúV.

Roth, K. J., Druker, S. L., Garnier, H. E., Lemmens, M., Chen, C., Kawanaka, T., ... War$\mathrm{vi}$, D. (2006). Teaching science in five countries: Results from the TIMSS 1999 video study. Washington: U. S. Government Printing Office.

Rowe, M. B. (1986). Wait time: Slowing down may be a way of speeding up! Journal of Teacher Education, 37(1), 43-50.

Rusk, F., Pörn, M., Sahlström, F., \& Slotte-Lüttge, A. (2015). Perspectives on using video recordings in conversation analytical studies on learning in interaction. International Journal of Research \& Method in Education, 38(1), 39-55.

Sacks, H., Schegloff, E. A., \& Jefferson, G. (1974). A simplest systematics for the organization of turn-taking for. Language, 50(4), 696-735.

Schegloff, E. A., Jefferson, G., \& Sacks, H. (1977). The preference for self-correction in the organization of repair in conversation. Language, 53(2), 361-382.

Sinclair, J. M., \& Coulthard, M. (1975). Towards an analysis of discourse: The English used by teachers and pupils. Oxford: Oxford University Press.

Skukauskaite, A., Rangel, J., Rodriguez, L. G., \& Ramón, D. K. (2015). Understanding classroom discourse and interaction: Qualitative perspectives. In N. Markee (Ed.), The handbook of classroom discourse and interaction (s. 44-59). Hoboken: Wiley.

Slavík, J., Chrz, V., Štech, S., Nohavová, A., Klumparová, Š., Hník, O., ... Valenta, J. (2013). Tvorba jako způsob poznávání. Praha: Karolinum.

Sternberg, R. (2009). Kognitivní psychologie. Praha: Portál.

Stone, C. A. (1998). The metaphor of scaffolding: Its utility for the field of learning disabilities. Journal of Learning Disabilities, 31(4), 344-364.

Šed’ová, K., Švaříček, R., Makovská, Z., \& Zounek, J. (2011). Dialogické struktury ve výukové komunikaci na druhém stupni základní školy. Pedagogika, 61(1), 13-33.

Švaříček, R. (2011). Funkce učitelských otázek ve výukové komunikaci na druhém stupni základní školy. Studia paedagogica, 16(1), 9-46.

Ten Have, P. (2007). Doing conversation analysis. London: Sage.

Tharp, R. G., \& Gallimore, R. (1988). Rousing minds to life: Teaching, learning, and schooling in social context. Cambridge: Cambridge University Press.

Tobin, K. (1987). The role of wait time in higher cognitive level learning. Review of Educational Research, 57(1), 69-95.

Tobin, K., Ritchie, S. M., Oakley, J. L., Mergard, V., \& Hudson, P. (2013). Relationships between emotional climate and the fluency of classroom interactions. Learning Environments Research, 16(1), 71-89.

Tůma, F. (2014). Dialogismus a výzkum interakce ve třídě: přehledová studie (1990-2012). Pedagogika, 64(2), 177-199.

Tůma, F. (2016). Konverzační analýza a interakce ve třídě: východiska a metodologické aspekty. Pedagogická orientace, 26(3), 415-441.

Tůma, F. (2017). Interakce ve výuce anglického jazyka na vysoké škole pohledem konverzační analýzy. Brno: MU.

Van de Pol, J., Volman, M., \& Beishuizen, J. (2010). Scaffolding in teacher-student interaction: A decade of research. Educational Psychology Review, 22(3), 271-296.

Wells, G. (1993). Reevaluating the IRF sequence: A proposal for the articulation of theories of activity and discourse for the analysis of teaching and learning in the classroom. Linguistics and Education, 5(1), 1-37. 
76 Wood, D., Bruner, J. S., \& Ross, G. (1976). The role of tutoring in problem solving. Journal of Child Psychology and Psychiatry, 17(2), 89-100.

Wood, T., Williams, G., \& McNeal, B. (2006). Children's mathematical thinking in different classroom cultures. Journal for Research in Mathematics Education, 37(3), 222-255.

Woods-McConney, A., Wosnitza, M., \& Sturrock, K. L. (2016). Inquiry and groups: Student interactions in cooperative inquiry-based science. International Journal of Science Education, 38(5), 842-860.

Mgr. Tereza Češková Institut výzkumu školního vzdělávání a katedra geografie Pedagogická fakulta, Masarykova univerzita Poříčí 7/9, 60300 Brno ceskova@ped.muni.cz 


\section{Přiloha}

\section{Ukázka 1}

\section{CS14 (14:54-18:26)}

01 U: Takže ted'ka bysme se na to podívali (.) a schválně $(2,5)$

02 co si myslíte, že bude jedno z prvních, čím se teda ten člověk začal=

03 ZZ: =.h

04 U: od těch (.) svých [živočišných] přibuzných lišit.

05 ((souhlasně pokývne, jde zapsat na tabuli))

06 ZZ: [Vzprímený pohyb]. ((Žák vykřikne bez vyvolání))

07 U: Čím si myslíte, že je to výhodný se=?

08 Z: =Abysme viděli.=

$09 \mathrm{Z:}=$ =Na páteř.

10 Z: [Abysme viděli.] ((opakuje stejná žákyně, U ale opravuje „na páteř“))

11 U: [No to bohužel] není vůbec výhodný.= ((U pokývnutím vyvolá))

12 Z: =Abysme viděli. ((tentokrát opakuje jiný - vyvolaný - žák))

13 U: Abysme viděli, to je ono, jo. Někde ve vysoké trávě,

14 abychom na sebe viděli, což je úplně úplně supr.

15 A další věc ještě? (2)

16 Z: Málo srsti.

17 Z: Málo srsti.

$18 \mathrm{U}$ : Ne, myslím ještě pořád ten vzprímený pohyb,

19 U: $k$ čemu to bylo dobrý=

20 Z: =Kvưli rychlosti. Protože je to rychlejší. ((vyvolaný Z, U čeká, jiný žák názor neguje))

21 Z: Není.

22 U: Není bohužel teda. Jako (...) chvílema to může být rychlejší, ale

23 chvílema taky ne. A není to pro nás až tak úplně nejvýhodnější (2).

24 Z: [Oheň.] ((vykřikne, U na odpověd' nereaguje a pokračuje))

25 U: [Něco jinýho.]

26 Z: Oheň=

27 U: =Představte si, že jsem lidoop prostě a takhle se pohybuju. Oni ještě nemají takhle ty ruce ((ukazuje)), oni mají takhle jenom ty hřbety ((ukazuje)), se opírají. Takhle se pohybuju ((ukazuje)), a najednou jdu takhle po dvou ((ukazuje)).(4) ((i přesto, že se již žáci hlásí))

31 ZZ: .h ((zvedají se ruce, U vyvolává))

32 Z: Protože chce třeba něco vzít do ruky nebo tak.

33 U: To je ono, jo. Já si vlastně uvolním ruce a najednou si můžu někde

34 něco přenášet a prostě se věnovat ještě něčemu jinýmu. Mám tady dvě ((ukazuje)) 
$7835 \quad$ končetiny, který prostě nemám zatižený tím přemíst’ováním se odněkud někam. (kráceno)

36 U: Co nám z toho vyplynulo, $z$ toho vzprímeného pohybu? Že jsme si

37 uvolnili ruce a co máme na rukou ještě jinačího? ((U ukazuje dlaň))=

38 ZZ: =Prsty

39 ZZ: klouby ((U hýbe palcem)) palec ((U dělá špetku)) (...)

40 Z: Máme pět končetin. ((Žák vykřikne, U nereaguje, ale reaguje jiný žák))

41 Z: Pět?

42 Z: Pět končetin?

43 Z: Houby, pět prstů. ((U se začne usmívat, nechává výměnu proběhnout))

44 U: To je zajímavý, kde jste tu pátou sebrali. No? ((vyvolá pokynutím))

45 Z: Jako pět prstů.

46 U: Pět prstů mají i opice. ((přikývne a vyvolá dalšího))

47 Z: Prostě jakože ten prst máme proti tomu.

$48 \mathrm{U}: \quad$ Tak, to je ono.((ukazuje na ruce) $)$ Ten palec= ((ukazuje opozici palce skrze špetku))

49 Z: =Mají delší tu (2) h, jako na uchopení...

50 U: ((U pokyvuje hlavou)) (1) Mají to na uchopení, ale spíš takhle dokolečka. 51 ((ukazuje rukou)) A my jsme schopni opravdu těma čtyřma prstama jít 52 takhle proti palci ((ukazuje rozdíl lidského a opičího úchopu)) a opravdu 53 teda manipulovat s předměty hodně jemněji a citlivěji. Jo, že prostě něco vezmeme

54 ((vezme tužku)) a prostě už teda s tím pracujeme mnohem líp. Takže dáme (...).

55 Tomu se ř́ká, děcka, že je palec v opozici. 
AS8 (41:05-43:48)

01 U: Dobře (pšt) ((prstem i ukáže)) máme zjištěno, že to byl tady

$02 \quad$ ((ukazuje rukou ven z okna)) od vedlejší

03 vesnice soused jeden kluk, který to sem přišel vysypat

04 ((ukazuje rukou na odpadky)). Mávnutím kouzelného [proutku]

$05 \quad$ ((Pssst, mávne jakoby proutkem)) (1) nejste policisté,

06 jste soudci. (2) My víme, že, co dělá soudce?

(kráceno)

07 Co ((ukazuje prstem na pusu na znamení ticha))

$08 \quad$ vymyslíte jako soudci? (3)

(kráceno)

09 U: (2) Čekám. (1) TICHO V SOUDNÍ SíNI, jak říká Nikolas. ((vyvolá))

10 Z: Pochválíme ho.

11 U: A budeme se předvádět se tady, ano ((mávne rezignovaně rukou)),

12 to je typické pro pát'áky na konci roku. No, takže Abdul by ho

13 pochválil, dobře, ještě by mu koupil čokoládu ((ukáže na Abdula)).

14 ZZ: ((smích))

15 U: Takže je to správné? ((pokyvuje hlavou na znamení, že souhlasí))

16 ZZ: Ne, není=

17 U: =Aha: Takže tady se nám kluci projevují tak jak v 5. třídě a v 6.? ((vyvolá))

18 Z: Dva měsíce prospěšných prací.

19 U: To ((ukáže na Z, která mluvila)), čili, my bychom mu to mohli dát (2),

20 co, Žando (2), co bychom mu to mohli dát?

21 Z: Že to bude čistit=

$22 \mathrm{U:}=$ [Že to bude čistit.]

23 Z: [Dva roky a bude to udržovat.] (kráceno)

24 Z: .h Aby zaplatil pokutu.((žákyně vykřikne))

25 U: Pokutu, ano ((ukazuje na žákyni)) //

26 výborně, tady už jsou konstruktivní věci. ((vyvolá dalšího))

27 Z: // Padesát tisíc.

28 Z: Prospěšné práce

29 U: Prospěšné práce, vyčistit rybník ((ukazuje na toho, kdo to řekl)),

30 zaplatit pokutu ((ukazuje, souhlasně pokyvuje)).

$31 \quad K l u c i$ (1.5), vám by se to líbilo, kdyby vám to vysypali před dům?

32 ((ukazuje na bavící se dvojici žáků)) // Na zahradu. Filipovi ano

33 ((ukazuje na Filipa)), on by se $v$ tom rochnil.

34 Z: // Jo.

35 ZZ: ((smích)) 
8036 U: Kájo. ((pohledem vyvolá))

37 Z: Šel by do pastáku.

38 U: (1) ((pokyvuje váhavě hlavou)) Není to tak jednoduchá věc,

39 představuješ si tohle, že by šel do pastáku. To by musel takových

40 věcí udělat daleko víc=

41 Z: =Když tam navezl náklad'ák odpadkư? ((váhavě pokyvuje hlavou))

42 Z: Tady už je jedna chcíplá. ((ukazuje na rybu))

43 U: Vidíte to, Tomáš zjistil, že už mu// chcípla rybička, jeho.

44 Takže, vidíte ten důsledek.

45 Z: // A jmenovala se Toník

46 Z: Fuj ta smrdí.((smích))

47 U: Tomi, já tě poprosím (2), zahraješ si na toho kluka,

48 který to tady vysypal //, dostaneš prospěšné práce.

49 Z: // Já chci!

50 U: Týden prospěšných prací a jedna $z$ těch prací je,

51 že tě poprosím, zajdi k paní uklízečce pro smetáček a lopatku. 